\title{
Selective Anticancer and Antimicrobial Metallodrugs Based on Gold(III) Dithiocarbamate Complexes
}

\author{
Elisa Abás ${ }^{1,2, *}$, Diego Aguirre-Ramírez ${ }^{2}\left(\mathbb{D}\right.$, Mariano Laguna ${ }^{1}$ (D) and Laura Grasa $2,3,4, *(\mathbb{D})$ \\ 1 Departamento de Química Inorgánica, Instituto de Síntesis Química y Catálisis Homogénea, Universidad de \\ Zaragoza-CSIC, Plaza S. Francisco s/n, 50009 Zaragoza, Spain; mlaguna@unizar.es \\ 2 Departamento de Farmacología, Fisiología y Medicina Legal y Forense, Facultad de Veterinaria, Universidad \\ de Zaragoza, Miguel Servet, 177, 50013 Zaragoza, Spain; diego23aguirre@outlook.com \\ 3 Instituto de Investigación Sanitaria de Aragón (IIS Aragón), 50009 Zaragoza, Spain \\ 4 Instituto Agroalimentario de Aragón -IA2, Universidad de Zaragoza-CITA, 50013 Zaragoza, Spain \\ * Correspondence: 113elisa@gmail.com (E.A.); lgralo@unizar.es (L.G.)
}

Citation: Abás, E.; Aguirre-Ramírez, D.; Laguna, M.; Grasa, L. Selective

Anticancer and Antimicrobial Metallodrugs Based on Gold(III) Dithiocarbamate Complexes. Biomedicines 2021, 9, 1775. https://doi.org/10.3390/ biomedicines 9121775

Academic Editor: Muhammad Hanif

Received: 15 October 2021

Accepted: 24 November 2021

Published: 26 November 2021

Publisher's Note: MDPI stays neutral with regard to jurisdictional claims in published maps and institutional affiliations.

Copyright: (C) 2021 by the authors Licensee MDPI, Basel, Switzerland. This article is an open access article distributed under the terms and conditions of the Creative Commons Attribution (CC BY) license (https:// creativecommons.org/licenses/by/ $4.0 /)$

\begin{abstract}
New dithiocarbamate cycloaurated complexes have been synthesized and their physicochemical and in vitro antitumor properties have been evaluated. All the performed studies highlighted good transport through the blood and biodistribution, according to the balance between the properties of hydrophilicity/lipophilicity and the binding of moderate strength to the BSA protein. Furthermore, none of the complexes exhibited reduction or decomposition reactions, presenting excellent physiological stability. The in vitro cytotoxic effect was evaluated on human colon cancer cell line Caco-2/TC7, and the complexes showed great antiproliferative activity and excellent selectivity, as much less effect was detected on normal Caco-2/TC7 cells. Most of the complexes exhibit antiproliferative activity that was better than or similar to auranofin, and at least nine times better than that of cisplatin. Its action mechanism is still under discussion since no evidence of cell cycle arrest was found, but an antioxidant role was shown for some of the selective complexes. All complexes were also tested as antimicrobial drugs, exhibiting good activity towards S. aureus and $E$. coli. bacteria and C. albicans and C. neoformans fungi.
\end{abstract}

Keywords: dithiocarbamate; cycloaurated; anticancer drugs; antimicrobial drugs; cell cycle; oxidative stress damage; apoptosis

\section{Introduction}

Since the serendipitous discovery of cisplatin (cis- $\left.\left[\mathrm{PtCl}_{2}\left(\mathrm{NH}_{3}\right)_{2}\right]\right)$ as an antitumor drug and its use in the clinic since 1978 [1], the field of investigation of metallodrugs as anticancer agents has been kept open. The main effort is focused on achieving more specific and selective drugs than cisplatin in order to hopefully erase the severe side-effects evoked by this treatment [2,3]. Platinum-based anticancer drugs have also been developed during this time, and four platinum(II) drugs are approved for use in chemotherapy [4], although cisplatin continues to be the most widely used together with the second-generation drug carboplatin $\left[\mathrm{Pt}\left(\mathrm{NH}_{3}\right)_{2}\left(\mathrm{CBDCA}-\mathrm{O}, \mathrm{O}^{\prime}\right)\right]$. Another important limitation of platinum drugs is the developing resistances shown by some kinds of tumors. For these reasons, other transition metals such as iron [5], copper [6], ruthenium [7-9], and gold [10-12], among others [13], have been considered as anticancer drugs and the results obtained in these studies are promising. The use of gold in medicine comes from its traditional use in medicine as antiarthritic agents such as gold(I) thiomalate (myocrisin), gold(I) thioglucose (solganol), and 2,3,4,6-tetra-o-acetyl-1-thio-b-D-glucopyranosato-(S)-triethylphosphine gold(I) (auranofin) (Figure 1). Some of these complexes, clinically established as antiarthritic gold(I) compounds, have shown significant antitumor properties. This dual application may be related to an anti-inflammatory effect of the gold complexes because as cancer, rheumatoid arthritis usually involves inflammatory processes [14-16]. 


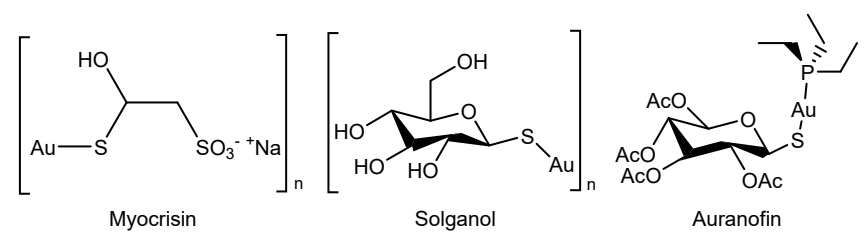

Figure 1. Approved antiarthritic gold(I) drugs.

Although gold(III) complexes seem to be better candidates to replace platinum-based drugs owing to their isostructural and isoelectronic behavior to platinum(II), the development of gold(III) complexes as alternative antitumor agents has been hindered by their poor stability under physiological conditions. This problem has been solved in the literature by the coordination of multidentate ligands to the gold center and therefore, cyclometallation is a good strategy to enhance their stability. Several cyclometalating ligands exist, where $\mathrm{C}^{\wedge} \mathrm{N}$ is especially interesting due to the possibility of coordinating different ancillary ligands to optimize the final drug design [17-20]. In the literature, several examples of cyclometalated gold(III) complexes with $\left(\mathrm{C}^{\wedge} \mathrm{N}\right),\left(\mathrm{N}^{\wedge} \mathrm{N}^{\wedge} \mathrm{C}\right)$, or $\left(\mathrm{C}^{\wedge} \mathrm{N}^{\wedge} \mathrm{C}\right)$ ligands have been studied [21], showing promising antitumor properties. Another important family of bidentate ligands to stabilize $\mathrm{Au}^{3+}$ cations is dithiocarbamate ligands (DTC). Some of these complexes have shown great antiproliferative effects and stability [22-24]. As mentioned, the goal of the search for an alternative to platinum drugs is to avoid the resistance mechanism and the lack of selectivity. For this purpose, achieving drugs based on dithiocarbamate complexes with different action mechanisms would have a remarkable benefit against the lack of selectivity [25-27]. Based on these previous results, even with metals other than gold [28-31], in this work we focused on the synthesis of different cyclometalated gold(III) dithiocarbamate complexes with formula $\left[\mathrm{Au}\left(\mathrm{C}^{\wedge} \mathrm{N}\right)(\mathrm{DTC})\right] \mathrm{PF}_{6}$ using biphenyl ligands such as 2-( $p$-tolyl)pyridinate (tpy) and 2-phenylpyridinate (ppy) as cyclometalating ligands for a potential chemotherapy application.

On the other hand, the world is facing a crisis in treating infectious diseases, with a scarcity of new antibiotics in development to treat the growing threat of drug-resistant "superbugs" [32]. For this reason, the discovery of new antimicrobial drugs to treat some serious and life-threatening diseases is a research field of great interest. In this context, there is a large history of metallic compounds with antimicrobial properties such as cobalt [33], copper [34], and silver [35]. However, there are only a few examples of highly active gold complexes. It has been demonstrated that cyclometalated complexes have antibacterial properties, and this activity could be increased by chelating a metal to the active ligand [36]. In this work, we evaluate the antibacterial and antifungal activity of the newly synthesized cyclometalated gold(III) dithiocarbamate complexes.

\section{Materials and Methods}

\subsection{Chemicals}

${ }^{1} \mathrm{H}$ and APT spectra were recorded on 400 or $300 \mathrm{MHz}$ Bruker Avance spectrometers (Billerica, MA, USA) and were referenced to external TMS. Chemical shifts ( $\delta$ ) are given in ppm, and coupling constants are reported in $\mathrm{Hz}$ (Figure S1). MALDI mass spectra were measured on a Micromass Autospec spectrometer (Waters Corporation, Milford, MA, USA) in positive ion mode using DCTB (1,1-diciano-4-tbutylphenyl-3-methylbutadiene) as the matrix. Infrared spectra $\left(4000-250 \mathrm{~cm}^{-1}\right)$ were recorded on a Perkin Elmer Spectrum 100 FTIR (far-IR) spectrometer (Zaragoza, Spain). Elemental analyses were obtained inhouse using a Perkin Elmer 2400 Series II CHNS/O System elemental analyzer. The starting material $\mathrm{HAuCl}_{4}$ was gently donated by Torrecid S.A. Starting cyclometalated complexes $\left[\mathrm{Au}\left(\mathrm{C}^{\wedge} \mathrm{N}\right) \mathrm{Cl}_{2}\right], \mathrm{C}^{\wedge} \mathrm{N}$ : 2-(p-tolyl)pyridinate (tpy), and 2-phenylpyridinate (ppy) were obtained using a slightly modified previously described procedure [37,38]. 


\subsection{Synthesis of Dithiocarbamate Gold(III) Cyclometalated Complex}

The synthesis of dithiocarbamate gold(III) cyclometalated complexes was performed according to the protocols described before [39]. A solution of the corresponding cyclometalated complex $(0.5 \mathrm{mmol})$ in acetonitrile was added to a sodium dialkyldithiocarbamate ( $0.5 \mathrm{mmol})$ (Alkyl: Methyl, Ethyl and Benzyl) solution in acetone dropwise to make a pale yellow-orange solution. After $30 \mathrm{~min}$ of stirring, a solution of potassium hexafluorophosphate $(0.55 \mathrm{mmol})$ in methanol was added, enhancing the yellow color. The mixture was stirred for an additional hour and the precipitated product was filtered off and washed with distilled water $(2 \times 3 \mathrm{~mL})$ and acetone $(2 \times 3 \mathrm{~mL})$.

Complex [Au(tpy)(dmdtc)] $\mathrm{PF}_{6}, \mathrm{C} 1$ : Yield, $71 \%{ }^{1} \mathrm{H}$ NMR $\left(400 \mathrm{MHz}, \mathrm{CDCl}_{3}\right) \delta 8.91$ $(\mathrm{d}, \mathrm{J}=5.4 \mathrm{~Hz}, 1 \mathrm{H}), 8.56-8.50(\mathrm{~m}, 1 \mathrm{H}), 7.86(\mathrm{~s}, 1 \mathrm{H}), 7.84(\mathrm{~s}, 1 \mathrm{H}), 7.48-7.41(\mathrm{~m}, 2 \mathrm{H}), 7.20(\mathrm{~d}$, $\mathrm{J}=7.3 \mathrm{~Hz}, 1 \mathrm{H}), 3.16(\mathrm{~s}, 3 \mathrm{H}), 3.07(\mathrm{~s}, 3 \mathrm{H}), 2.45(\mathrm{~s}, 3 \mathrm{H})$. IR: $v\left(\mathrm{~cm}^{-1}\right)=3088,3039,1605,1593$, 1434, 1252, 1166, 1033, 888, 844, 821, 769, 731, 695, 416. MS (MALDI, DCTB): 485.1 (95, $\mathrm{M}-\mathrm{PF}_{6}$ ). Anal. Calcd for $\mathrm{C}_{15} \mathrm{H}_{16} \mathrm{AuF}_{6} \mathrm{~N}_{2} \mathrm{PS}_{2}: \mathrm{C}, 28.58 ; \mathrm{H}, 2.56 ; \mathrm{N}, 4.44 ; \mathrm{S}, 10.17$. Found: $\mathrm{C}$, 28.63; $\mathrm{H}, 2.60 ; \mathrm{N}, 4.39 ; \mathrm{S}, 10.21$.

Complex [Au(ppy)(dmdtc)]PF 6 , C2: Yield, $74 \%{ }^{1} \mathrm{H}$ NMR $\left(400 \mathrm{MHz}, \mathrm{CDCl}_{3}\right) \delta 9.84(\mathrm{~d}$, $\mathrm{J}=5.9 \mathrm{~Hz}, 1 \mathrm{H}), 8.18-8.12(\mathrm{~m}, 1 \mathrm{H}), 8.07(\mathrm{dd}, \mathrm{J}=8.0,1.2 \mathrm{~Hz}, 1 \mathrm{H}), 7.92(\mathrm{~d}, \mathrm{~J}=7.8 \mathrm{~Hz}, 1 \mathrm{H})$, 7.58-7.54 (m, 2H), 7.44-7.38 (m, 1H), $7.36(\mathrm{dd}, \mathrm{J}=10.7,4.7 \mathrm{~Hz}, 1 \mathrm{H}), 3.51(\mathrm{~s}, 3 \mathrm{H}), 3.48(\mathrm{~s}, 3 \mathrm{H})$. IR: $v\left(\mathrm{~cm}^{-1}\right)=3376,3093,1980,1716,1578,1408,832,761,557,411 . \mathrm{MS}^{+}$(MALDI, DCTB): $471.0\left(100,\left(\mathrm{M}^{-\mathrm{PF}_{6}}\right)^{+}\right)$. Anal. Calcd for $\mathrm{C}_{14} \mathrm{H}_{14} \mathrm{AuF}_{6} \mathrm{~N}_{2} \mathrm{PS}_{2}: \mathrm{C}, 27.28 ; \mathrm{H}, 2.29 ; \mathrm{N}, 4.55 ; \mathrm{S}, 10.41$. Found: $\mathrm{C}, 27.35 ; \mathrm{H}, 2.23 ; \mathrm{N}, 4.52 ; \mathrm{S}, 10.37$.

Complex [Au(tpy)(dedtc)] $\mathrm{PF}_{6}$, C3: Yield, 98\% ${ }^{1} \mathrm{H}$ NMR (400 MHz, acetone) $\delta 8.82$ $(\mathrm{ddd}, \mathrm{J}=5.8,1.4,0.7 \mathrm{~Hz}, 1 \mathrm{H}), 8.48(\mathrm{ddd}, \mathrm{J}=8.2,7.4,1.5 \mathrm{~Hz}, 1 \mathrm{H}), 8.44-8.39(\mathrm{~m}, 1 \mathrm{H}), 7.96(\mathrm{~d}$, $\mathrm{J}=7.9 \mathrm{~Hz}, 1 \mathrm{H}), 7.76(\mathrm{ddd}, \mathrm{J}=7.4,5.8,1.6 \mathrm{~Hz}, 1 \mathrm{H}), 7.39(\mathrm{ddd}, \mathrm{J}=7.9,1.5,0.7 \mathrm{~Hz}, 1 \mathrm{H}), 7.03$ $(\mathrm{dd}, \mathrm{J}=1.4,0.7 \mathrm{~Hz}, 1 \mathrm{H}), 4.07(\mathrm{q}, \mathrm{J}=7.3 \mathrm{~Hz}, 2 \mathrm{H}), 4.03(\mathrm{q}, \mathrm{J}=7.3 \mathrm{~Hz}, 2 \mathrm{H}), 2.45(\mathrm{~s}, 3 \mathrm{H}), 1.53$ $(\mathrm{t}, \mathrm{J}=7.3 \mathrm{~Hz}, 3 \mathrm{H}), 1.48(\mathrm{t}, \mathrm{J}=7.2 \mathrm{~Hz}, 3 \mathrm{H})$. APT $\left(101 \mathrm{MHz}, \mathrm{CDCl}_{3}\right) \delta 152.48,150.22,144.77$, 144.44, 130.92, 129.68, 127.77, 126.50, 122.97, 49.64-48.12, 21.72, 12.81-12.45. IR: $v\left(\mathrm{~cm}^{-1}\right)$ $=2978,2249,1605,1562,1465,1285,1037,822,774,554 . \mathrm{MS}^{+}$(MALDI, DCTB): 513.0 (98, $\left.\left(\mathrm{M}-\mathrm{PF}_{6}\right)^{+}\right)$. Anal. Calcd for $\mathrm{C}_{17} \mathrm{H}_{20} \mathrm{AuF}_{6} \mathrm{~N}_{2} \mathrm{PS}_{2}: \mathrm{C}, 31.01 ; \mathrm{H}, 3.06 ; \mathrm{N}, 4.25 ; \mathrm{S}, 9.74$. Found: $\mathrm{C}$, 31.09; $\mathrm{H}, 3.10 ; \mathrm{N}, 4.29 ; \mathrm{S}, 9.79$.

Complex [Au(ppy)(dedtc)] $\mathrm{PF}_{6}, \mathrm{C} 4$ : Yield, $79 \%{ }^{1} \mathrm{H}$ NMR (400 MHz, acetone) $\delta 8.64$ $(\mathrm{ddd}, \mathrm{J}=4.8,1.8,0.9 \mathrm{~Hz}, 1 \mathrm{H}), 8.07-8.04(\mathrm{~m}, 1 \mathrm{H}), 7.88(\mathrm{dd}, \mathrm{J}=5.1,4.0,1 \mathrm{H}), 7.85-7.77(\mathrm{~m}, 1 \mathrm{H})$, 7.67-7.63 (m, 1H), $7.29(\mathrm{ddd}, \mathrm{J}=7.4,4.8,1.2 \mathrm{~Hz}, 1 \mathrm{H}), 7.24-7.20(\mathrm{~m}, 2 \mathrm{H}), 4.06(\mathrm{~m}, 2 \mathrm{H}), 3.77(\mathrm{q}$, $\mathrm{J}=7.0 \mathrm{~Hz}, 2 \mathrm{H}), 1.27(\mathrm{t}, \mathrm{J}=7.1 \mathrm{~Hz}, 3 \mathrm{H}), 1.23(\mathrm{~m}, 3 \mathrm{H}) . \mathrm{IR}: v\left(\mathrm{~cm}^{-1}\right)=2979,2231,1532,1477$, 1263, 1204, 985, 829, 753, 559, 427. $\mathrm{MS}^{+}$(MALDI, DCTB): $499.5\left(100,\left(\mathrm{M}_{-} \mathrm{PF}_{6}\right)^{+}\right)$. Anal. Calcd for $\mathrm{C}_{16} \mathrm{H}_{18} \mathrm{AuF}_{6} \mathrm{~N}_{2} \mathrm{PS}_{2}$ : C, 29.82; H, 2.82; N, 4.35; S, 9.95. Found: $\mathrm{C}, 29.88 ; \mathrm{H}, 2.89 ; \mathrm{N}, 4.31$; $\mathrm{S}, 9.89$.

Complex [Au(tpy)(dbdtc)]PF 6 , C5: Yield, $80 \%{ }^{1} \mathrm{H}$ NMR $(400 \mathrm{MHz}$, acetone) $\delta 9.66(\mathrm{~d}$, $\mathrm{J}=5.5 \mathrm{~Hz}, 1 \mathrm{H}), 8.15(\mathrm{t}, \mathrm{J}=8.2 \mathrm{~Hz}, 1 \mathrm{H}), 7.97(\mathrm{~d}, \mathrm{~J}=8.3 \mathrm{~Hz}, 1 \mathrm{H}), 7.74(\mathrm{~s}, 1 \mathrm{H}), 7.59-7.45(\mathrm{~m}$, 2H), $7.16(\mathrm{~d}, \mathrm{~J}=7.7 \mathrm{~Hz}, 1 \mathrm{H}), 5.26(\mathrm{~s}, 2 \mathrm{H}), 5.23(\mathrm{~s}, 2 \mathrm{H}) .2 .38(\mathrm{~s}, 3 \mathrm{H})$. APT $\left(101 \mathrm{MHz}, \mathrm{CDCl}_{3}\right)$ $\delta$ 145.70, 142.80, 132.20, 129.99, 125.40, 123.80, 120.60, 77.16, 29.86. $\mathrm{MS}^{+}$(MALDI, DCTB): $485.0\left(4,\left(\mathrm{M}-2 \mathrm{Ph}-\mathrm{PF}_{6}\right)^{+}\right), 637.0\left(17,\left(\mathrm{M}-\mathrm{PF}_{6}\right)^{+}\right)$. Anal. Calcd for $\mathrm{C}_{27} \mathrm{H}_{24} \mathrm{AuF}_{6} \mathrm{~N}_{2} \mathrm{PS}_{2}$ : C, 41.44; $\mathrm{H}, 3.09 ; \mathrm{N}, 3.58 ; \mathrm{S}, 8.19$. Found: $\mathrm{C}, 41.50 ; \mathrm{H}, 3.01 ; \mathrm{N}, 3.65 ; \mathrm{S}, 8.23$.

Complex [Au(ppy)(dbdtc)] $\mathrm{PF}_{6}, \mathrm{C} 6:$ Yield, $76 \%{ }^{1} \mathrm{H}$ NMR $(400 \mathrm{MHz}$, acetone) $\delta 8.94$ $(\mathrm{d}, \mathrm{J}=5.5 \mathrm{~Hz}, 1 \mathrm{H}), 8.53(\mathrm{~m}, 2 \mathrm{H}), 8.13(\mathrm{~d}, \mathrm{~J}=7.7 \mathrm{~Hz}, 1 \mathrm{H}), 7.82(\mathrm{td}, \mathrm{J}=5.9,3.0 \mathrm{~Hz}, 1 \mathrm{H})$, $7.59(\mathrm{t}, \mathrm{J}=7.6 \mathrm{~Hz}, 1 \mathrm{H}), 7.49-7.44(\mathrm{~m}, 11 \mathrm{H}), 7.28(\mathrm{~d}, \mathrm{~J}=7.7 \mathrm{~Hz}, 1 \mathrm{H}), 5.24(\mathrm{~s}, 2 \mathrm{H}), 5.21(\mathrm{~s}$, 2H). APT (101 MHz, $\left.\mathrm{CDCl}_{3}\right) \delta 142.91,132.65,131.81,129.38,129.29,129.13,128.51,128.21$, 127.30, 125.57, 124.44, 120.92, 57.04. IR: $v\left(\mathrm{~cm}^{-1}\right)=3071,2161,1978,1698,1606,1530,1443$, 1246, 832, 759, 733, 702, 556. $\mathrm{MS}^{+}$(MALDI, DCTB): $623.0\left(100,\left(\mathrm{M}-\mathrm{PF}_{6}\right)^{+}\right)$. Anal. Calcd for $\mathrm{C}_{26} \mathrm{H}_{22} \mathrm{AuF}_{6} \mathrm{~N}_{2} \mathrm{PS}_{2}$ : C, 40.63; H, 2.89; N, 3.65; S, 8.34. Found: C, 40.69; H, 2.81; N, 3.58; $\mathrm{S}, 8.29$. 


\subsection{Distribution Coefficient $\left(\log P_{7.4}\right)$}

The $n$-octanol/water coefficient of the complexes was determined using the shakeflask method previously described [40]. Buffered-saline distilled water $(100 \mathrm{~mL}$, phosphate buffer $\mathrm{PO}_{4}{ }^{3-}=10 \mathrm{mM},(\mathrm{NaCl}=0.15 \mathrm{M}, \mathrm{pH} 7.4)$ and $n$-octanol $(100 \mathrm{~mL})$ were shaken together for $72 \mathrm{~h}$ to allow the saturation of both phases. Approximately $1 \mathrm{mg}$ of the complexes was dissolved in $5 \mathrm{~mL}$ of the aqueous phase, and $5 \mathrm{~mL}$ of the organic phase was added, mixing for $10 \mathrm{~min}$. The resulting emulsion was centrifuged to separate the phases. The concentration of the compounds in each phase was determined using UV-Vis absorbance spectroscopy. $\log \mathrm{P}_{7.4}$ was calculated as $\log \left(\mathrm{Abs}_{\text {organic }} / \mathrm{Abs}_{\text {aqueous }}\right)$.

\subsection{Solution Chemistry}

The stability of the gold complexes was analyzed by absorption UV spectroscopy. UV-Vis absorption spectra of the complexes were recorded on a Thermo Scientific spectrophotometer (Madrid, Spain). Solutions of C1-6 $\left(5 \times 10^{-5} \mathrm{M}\right)$ in $10 \mathrm{mM}$ phosphate buffer ( $\mathrm{pH}=7.4,137 \mathrm{mM} \mathrm{NaCl}$ ) were prepared from $20 \mathrm{mM}$ DMSO solutions of the complexes and thereafter monitored by measuring the electronic spectra over $24 \mathrm{~h}$ at $37^{\circ} \mathrm{C}$. To evaluate the stability in the presence of biological reductants, all complexes were pre-solved in a minimum amount of DMSO and then diluted in $10 \mathrm{mM}$ phosphate buffer $(\mathrm{pH}$ 7.4, $20 \mathrm{mM} \mathrm{NaCl}$ ) to a final concentration of $10 \mu \mathrm{M}$ [41]. All experiments were measure on a quartz microplate. Studies with L-glutathion reduced (GSH) and ascorbic acid (AsA) were conducted by increasing the final concentration of 0 to $50 \mu \mathrm{M}(\mathrm{GSH})$ and from $0-20 \mu \mathrm{M}$ for AsA.

\subsection{BSA Interaction Studies}

BSA was commercially available from Sigma Aldrich. A $2 \mathrm{mM}$ solution of BSA was prepared in PBS $(10 \mathrm{mM}, \mathrm{pH}=7.4)$. The final concentration of the stock BSA solution was checked by UV-Vis spectra $\left(\varepsilon_{279} \mathrm{~nm}=43,824 \mathrm{M}^{-1} \mathrm{~cm}^{-1}\right)$. The value obtained was the real concentration of the stock solution. A $6 \mathrm{mM}$ stock solution of the gold complexes in DMSO was prepared and different aliquots of the gold complex were added to a $50 \mu \mathrm{M}$ solution of BSA in PBS and placed in a quartz cuvette of $1 \mathrm{~cm}$ optical path. The fluorescence spectra were recorded on a Horiba Jobin Yvon (Bensheim, Germany) fluorolog FL-3-11 spectrometer. The samples were excited at $295 \mathrm{~nm}$ and the emission spectra were recorded in a range from 310 to $450 \mathrm{~nm}$ with emission slits set to $2 \mathrm{~nm}$. The fluorescence was measured for $4 \mathrm{~min}$ after every addition of the gold complex aliquots. The fluorescence intensities of the PBS and the gold complexes were irrelevant under the described conditions.

The data were analyzed using the Stern-Volmer equation F0/F $=1+$ KSV (gold complex $)=1+\mathrm{Kq} \tau 0$ (gold complex) $(\tau 0=$ lifetime of BSA in absence of the quencher) to obtain the Stern-Volmer quenching constant $\left(\mathrm{K}_{\mathrm{SV}}\right)$ and the quenching rate constant $(\mathrm{Kq})$. The binding constant $(\mathrm{Kb})$ was quantified using the modified Stern-Volmer equation: log $\{(\mathrm{F} 0-\mathrm{F}) / \mathrm{F}\}=\log \mathrm{Kb}+n \log$ (gold complex) $(n=$ number of binding sites) $[42,43]$.

\subsection{Cell Culture}

This study was conducted in the human enterocyte-like cell line Caco-2/TC7 [44]. This cell line undergoes a process of spontaneous differentiation in culture that leads to the formation of a monolayer of cells, expressing the morphological and functional characteristics of the mature enterocytes. This differentiation process is growth-dependent, where the cells undergo differentiation from "undifferentiated proliferative crypt-type cells" in the exponential phase of growth, to "differentiated enterocyte-type cells" in the stationary phase [45]. The cell culture of Caco-2/TC7 cells (passages 30-50) was performed according to a previously reported method $[46,47]$.

\subsection{Cell Viability Assay}

Cell survival was measured using the MTT test [48]. The assay depends on the cellular reduction of 3-(4,5-dimethylthiazol-2-yl)-2,5-diphenyltetrazolium bromide (MTT, Sigma- 
Aldrich, Madrid, Spain) by the mitochondrial dehydrogenase of viable cells to a blue formazan product that can be measured spectrophotometrically, as previously described $[46,47]$.

\subsection{Apoptosis Studies}

For the studies of apoptosis, using the detection of phosphatidylserine in the outer layer of the plasma membrane, an Annexin V-FITC Apoptosis Detection kit (Immunostep, Salamanca, Spain) was used. After incubation with the complexes, the cells were collected and transferred to flow-cytometry tubes. A negative control was prepared with untreated cells, which was used to define the basal level of apoptotic, necrotic, or dead cells. The staining with Annexin V-FITC and 7-Aminoactinomycin D (7-AAD) was performed according to the manufacturer's recommendations. The cells were washed twice with temperate phosphate-buffered saline (PBS) and resuspended in $200 \mu \mathrm{L}$ of $1 x$ Annexin-binding buffer. After that, $2.5 \mu \mathrm{L}$ Annexin V-FITC and $2.5 \mu \mathrm{L}$ propidium iodide (PI) were added to each $50 \mu \mathrm{L}$ of cell suspension. After incubation for $15 \mathrm{~min}$ at RT in the dark, $400 \mu \mathrm{L}$ of $1 \times$ Annexin-binding buffer were added and analyzed by flow cytometry within $1 \mathrm{~h}$. The signal intensity was measured using a Gallios Flow Cytometer (Beckman Coulter, Brea, CA, USA) and analyzed using the Kaluza Analysis Software (Beckman Coulter).

\subsection{Cell Cycle Analyses}

After incubation with the complexes, the cells were collected, washed twice with PBS, fixed in $70 \%$ ice-cold ethanol, and stored at $4{ }^{\circ} \mathrm{C}$ for $24 \mathrm{~h}$. After centrifugation, cells were resuspended in PBS containing PI $(50 \mu \mathrm{g} / \mathrm{mL})$ and RNase A $(100 \mu \mathrm{g} / \mathrm{mL})$. After incubation for $30 \mathrm{~min}$ at RT in the dark, PI-stained cells were analyzed for DNA content in a Gallios Flow Cytometer (Beckman Coulter). The red fluorescence emitted by PI was collected by a $620 \mathrm{~nm}$-long pass filter as a measure of the amount of DNA-bound PI and displayed on a linear scale. Cell cycle distribution was determined on a linear scale. The percentage of cells in cycle phases was determined using the Kaluza Analysis Software (Beckman Coulter).

\subsection{Oxidative Stress Damage}

Cell homogenates needed for this assay were prepared according to a previously described method [47]. Protein oxidation was analyzed by carbonyl-level measurement as previously described [49]. Cell homogenates were incubated with the classical carbonyl reagent 2,4-dinitrophenylhydrazine (DNPH), and protein carbonylation was measured spectrophotometrically at $375 \mathrm{~nm}$. The results were calculated in nmol carbonyl groups $\mathrm{mg}^{-1}$ protein.

\subsection{Antimicrobial Assays}

The antimicrobial assays were performed according to the protocols of the Community for Open Antimicrobial Drug Discovery (CO-ADD) [32]. C1-6 were prepared in DMSO and water to a final testing concentration of $32 \mu \mathrm{g} / \mathrm{mL}$ and serially diluted 1:2-fold 8 times. Each sample concentration was prepared in 384-well plates, non-binding surface plate (NBS; Corning 3640) for each bacterial/fungal strain, all in duplicate $(n=2)$, and keeping the final DMSO concentration to a maximum of $0.5 \%$. All the sample preparation was done using liquid-handling robots.

\subsubsection{Antibacterial Assay}

The antibacterial activity of all synthesized complexes was evaluated in five different pathogenic bacteria, including methicillin-resistant Staphylococcus aureus (Sa), Escherichia coli $(\mathrm{Ec})$, Klebsiella pneumonia $(\mathrm{Kp})$, Psedomonas aeruginosa $(\mathrm{Pa})$, and Acinetobacter baumannii $(\mathrm{Ab})$. All bacteria were cultured in cation-adjusted Mueller Hinton Broth (CAMHB) at $37^{\circ} \mathrm{C}$ overnight. A sample of each culture was then diluted 40-fold in fresh broth and incubated at $37^{\circ} \mathrm{C}$ for $1.5-3 \mathrm{~h}$. The resultant mid-log phase cultures were diluted $(\mathrm{CFU} / \mathrm{mL}$ measured by $\mathrm{OD}_{600}$ ), then added to each well of the complexes containing plates, giving a cell density 
of $5 \times 10^{5} \mathrm{CFU} / \mathrm{mL}$ and a total volume of $50 \mu \mathrm{L}$. All the plates were covered and incubated at $37^{\circ} \mathrm{C}$ for $18 \mathrm{~h}$ without shaking. The inhibition of bacterial growth was determined by measuring the absorbance at $600 \mathrm{~nm}\left(\mathrm{OD}_{600}\right)$ using a Tecan M1000 Pro monochromator plate reader (Männedorf, Switzerland). The percentage of growth inhibition was calculated for each well, using the negative control (media only) and positive control (bacteria without inhibitors) on the same plate as references. The percentage of growth inhibition was calculated for each well, using the negative control (media only) and positive control (bacteria without inhibitors) on the same plate. The MIC was determined as the lowest concentration at which the growth was fully inhibited, defined by an inhibition $\geq 80 \%$.

\subsubsection{Antifungal Assay}

The antifungal activity of all synthesized complexes was evaluated in two different fungi, Candida albicans (Ca) and Cryptococcus neoformans (Cn). Fungi strains were cultured for 3 days on yeast extract-peptone-dextrose (YPD) agar at $30^{\circ} \mathrm{C}$. A yeast suspension of $1 \times 10^{6}$ to $5 \times 10^{6} \mathrm{CFU} / \mathrm{mL}$ (as determined by $\mathrm{OD}_{530}$ ) was prepared from five colonies. The suspension was subsequently diluted and added to each well of the complex-containing plates, giving a final cell density of fungus suspension of $2.5 \times 10^{3}$ $\mathrm{CFU} / \mathrm{mL}$ and a total volume of $50 \mu \mathrm{L}$. All plates were covered and incubated at $35^{\circ} \mathrm{C}$ for $36 \mathrm{~h}$ without shaking. Growth inhibition of $C$. albicans was determined by measuring the absorbance at $630 \mathrm{~nm}\left(\mathrm{OD}_{630}\right)$, whereas the growth inhibition of $C$. neoformans was determined by measuring the difference in absorbance between 600 and $570 \mathrm{~nm}\left(\mathrm{OD}_{600-570}\right)$, after the addition of resazurin $\left(0.001 \%\right.$ final concentration) and incubation at $35{ }^{\circ} \mathrm{C}$ for $2 \mathrm{~h}$. The absorbance was measured using a Biotek Multiflo Synergy HTX plate reader (Winooski, VT, USA). In both cases, the percentage of growth inhibition was calculated for each well, using the negative control (media only) and positive control (fungi without inhibitors) on the same plate. The MIC was determined as the lowest concentration at which the growth was fully inhibited, defined by an inhibition $\geq 80 \%$ for C. albicans and an inhibition $\geq 70 \%$ for $C$. neoformans. Due to a higher variance in growth and inhibition, a lower threshold was applied to the data for $C$. neoformans.

\subsection{Statistical Analyses}

All results are expressed as means \pm the standard error of the mean (SEM) of at least three independent experiments. Statistical comparisons were performed using one-way ANOVA followed by the Bonferroni post-test and differences between $p$-values $<0.05$ were considered statistically significant. Statistical analyses conducted using the Prism GraphPad Program (Prism version 4.0, GraphPad Software, San Diego, CA, USA).

\section{Results and Discussion}

\subsection{Synthesis and Characterization}

The main strategy to achieve cyclometalated compounds with biphenyl ligands involves transmetalation processes with organomercurial complexes [37,50,51], but in our work great effort was made to develop new and direct synthetic routes without using any mercurial compounds. The most extended method is refluxing in $\mathrm{MeCN} /$ watering the precursor $\left[\mathrm{AuCl}_{3}\left(\mathrm{CH}^{\wedge} \mathrm{N}\right)\right][18,52,53]$; however, this procedure is not useful for cyclometalating ligands that require high $\mathrm{C}-\mathrm{H}$ bond activation. For this reason, the method developed by Grant et al. was chosen in order to obtain the desired cyclometalated precursor from an easy solventless thermal cyclometalation [38]. The dithiocarbamate derivatives were obtained by a one-pot reaction of the parent dichloro complex with the selected sodium salt of the DTC ligand. This reaction resulted in the substitution of both chlorides ligands and the formation of the cationic chelated complex. After $30 \mathrm{~min}$, potassium hexafluorophosphate was added to precipitate the desired complex (Scheme 1). Complexes C1-6, isolated with good yields (71\%-98\%), were characterized by ${ }^{1} \mathrm{H},{ }^{13} \mathrm{C}$ [54], mass spectrometry, IR, and elemental analysis. 


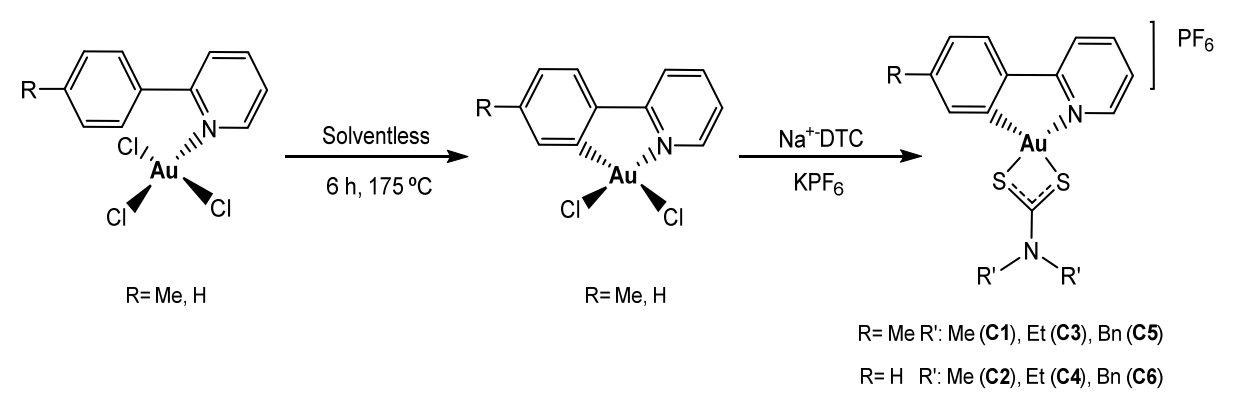

Scheme 1. Synthetic scheme to obtain cyclometalated $\left(\mathrm{C}^{\wedge} \mathrm{N}\right)$ gold(III) complexes.

${ }^{1} \mathrm{H}-\mathrm{NMR}$ data for these complexes are represented in Table 1, showing that the DTC ligand induced a high-field shift of the cyclometalated ligand signals compared to the cyclometalated precursors; although in the case of the complex with the DTC unit with the benzyl group (dbdtc) this effect was less important. In these ${ }^{1} \mathrm{H}-\mathrm{NMR}$ studies, the inequality of two different alkyl groups of the DTC moiety can be observed due to the different gold coordination environment.

Table 1. ${ }^{1} \mathrm{H}-\mathrm{NMR}$ data for biphenyl rings of gold complexes in $\mathrm{CDCl}_{3}$.

\begin{tabular}{|c|c|c|c|c|c|c|c|c|}
\hline \multirow{2}{*}{ Complex } & \multicolumn{4}{|c|}{ Pyridine } & \multicolumn{4}{|c|}{ Phenyl } \\
\hline & $\mathrm{H}_{1}$ & $\mathbf{H}_{2}$ & $\mathbf{H}_{3}$ & $\mathbf{H}_{4}$ & $\mathbf{H}_{5}$ & $\mathrm{H}_{6}$ & $\mathrm{H}_{7}$ & $\mathbf{H}_{8}$ \\
\hline$\left[\mathrm{Au}(\mathrm{tpy}) \mathrm{Cl}_{2}\right]$ & 9.79 & 7.46 & 8.10 & 7.84 & 7.42 & 7.40 & 7.85 & - \\
\hline$\left[\mathrm{Au}(\mathrm{ppy}) \mathrm{Cl}_{2}\right]$ & 9.84 & 7.51 & 8.14 & 7.92 & 7.56 & 7.40 & 7.36 & 8.07 \\
\hline$[\mathrm{Au}(\mathrm{tpy})(\mathrm{dmdtc})] \mathrm{PF}_{6}(\mathrm{C} 1)$ & 9.80 & 7.47 & 8.11 & 7.83 & 7.20 & 7.44 & 7.86 & - \\
\hline$[\mathrm{Au}(\mathrm{ppy})(\mathrm{dmdtc})] \mathrm{PF}_{6}(\mathrm{C} 2)$ & 8.69 & 7.21 & 7.71 & 7.80 & 7.59 & 7.21 & 7.21 & 8.02 \\
\hline$[\mathrm{Au}(\mathrm{tpy})(\mathrm{dedtc})] \mathrm{PF}_{6}(\mathrm{C} 3)^{1}$ & 8.82 & 7.76 & 8.48 & 8.41 & 7.96 & 7.39 & 7.03 & - \\
\hline$[\mathrm{Au}(\mathrm{ppy})(\mathrm{dedtc})] \mathrm{PF}_{6}(\mathrm{C} 4)$ & 8.69 & 7.21 & 7.72 & 7.86 & 7.58 & 7.21 & 7.21 & 7.97 \\
\hline$[\mathrm{Au}(\mathrm{tpy})(\mathrm{dbdtc})] \mathrm{PF}_{6}(\mathrm{C} 5)$ & 9.66 & 7.43 & 8.16 & 7.96 & 7.16 & 7.48 & 7.73 & - \\
\hline$[\mathrm{Au}(\mathrm{ppy})(\mathrm{dbdtc})] \mathrm{PF}_{6}(\mathrm{C} 6)$ & 9.82 & 7.52 & 8.15 & 7.92 & 7.55 & 7.36 & 7.36 & 8.05 \\
\hline
\end{tabular}

${ }^{1}$ In acetone- $\mathrm{d}_{6}$. dmdtc: dimethyl dithiocarbamate, dedtc: diethyl dithiocarbamate, dbdtc: dibenzyl dithiocarbamate. (-) Not applicable.

The IR spectra confirmed in all cases the total displacement of chloride ligands, since no bands were found around $320 \mathrm{~cm}^{-1}$ corresponding to $v(\mathrm{Au}-\mathrm{Cl})$. In contrast, a mediumintensity band above $1570 \mathrm{~cm}^{-1}$, attributed to the delocalized DTC $\mathrm{NCS}_{2}$ system [24], finally confirmed the chelation mode of the DTC ligand to the gold center. The MS-MALDI ${ }^{+}$ studies also pointed to the proposed structure, since a high intensity of the $\left[\mathrm{M}-\mathrm{PF}_{6}\right]^{+}$peak was recorded, being the base peak of the spectrum in most of the complexes. Furthermore, there was good equivalence between the experimental and theoretical isotopic distribution for some of the synthesized complexes (Figure S2).

\subsection{Lipophilicity Studies}

Biodistribution studies should be conducted to evaluate whether our complexes could reach their pharmacological target. The potential biodistribution of our complexes was evaluated by the measure of the partition coefficient. This parameter indicates how balanced the lipo- and hydrophilicity of the compounds are. Good equilibrium between these two properties is crucial for proper distribution inside the organism. The bloodstream is aqueous in nature, so hydrophilicity is needed for drug delivery, but too-high hydrophilicity can hinder the penetration of biological membranes. Of course, high lipophilicity behavior can hinder biomedical applications related to a good distribution profile [55]. The chosen method to measure the partition coefficient $\left(\log \mathrm{P}_{\text {ow }}\right)$ was the shake-flask technique $[40,56]$, with ideal values in the range of $-1 \leq \log \mathrm{P}$ ow $\leq 3$. However, for a greater oral and intestinal absorption, a more restricted range has values around 1.35-1.80 [57]. Table 2 collects all of the obtained $\log \mathrm{P}_{\text {ow }}$ values, and it can be seen that, although only complex $[\mathrm{Au}(\mathrm{ppy})(\mathrm{dedtc})] \mathrm{PF}_{6}(\mathrm{C} 4)$ satisfied this restricted range, all of them presented acceptable 
values of $\log \mathrm{P}_{\text {ow. }}$ It is especially significant that in all cases, complexes with ppy ligand exhibited more lipophilic behavior than the tpy-based complexes, which was surprising because the presence of the methyl group usually increases complex lipophilicity. Something similar happened with the dbdtc moiety, since the presence of two additional phenyl rings did not seem to have a great impact on the lipophilicity/hydrophilicity balance.

Table 2. Log $\mathrm{P}_{\mathrm{ow}}$ values of gold(III) dithiocarbamate complexes.

\begin{tabular}{ccccccc}
\hline Complex & C1 & C2 & C3 & C4 & C5 & C6 \\
\hline $\log \mathrm{P}_{\mathrm{ow}}$ & 0.61 & 1.11 & 1.17 & 1.57 & 0.89 & 1.00 \\
\hline
\end{tabular}

\subsection{Solution Behavior}

Due to the aqueous nature of the bloodstream, studies to understand the behavior of our complexes in such an environment were considered necessary in order to determine the stability in simulated physiological conditions, $\mathrm{pH}=7.4$ and $37^{\circ} \mathrm{C}$. By UV-Vis spectroscopy, the evolution over time of all synthesized complexes was followed for $24 \mathrm{~h}$. Compounds were initially dissolved in dimethyl sulfoxide $(20 \mu \mathrm{M})$ to reach a final concentration of $50 \mu \mathrm{M}$ in a phosphate buffer solution (PBS) that guaranteed $\mathrm{pH}=7.4$ and contained $\mathrm{NaCl}$ to achieve osmolality similar to that of the human body. All complexes exhibited great stability in this medium and showed two high-intensity intramolecular intraligand bands at 214 and $256 \mathrm{~nm}$, attributed to transitions located in the NCS and CSS moieties, respectively [58]. Besides, in the cases of complexes C1-4, a low-intensity broad band was detected (322 nm) (Figure 2 and Figure S3). This band was attributed to the LMCT transition, and it is very common in organometallic chemistry [59].

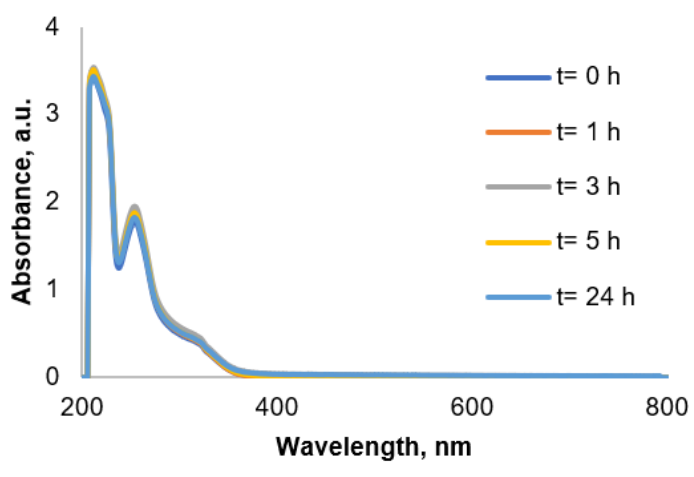

(a)

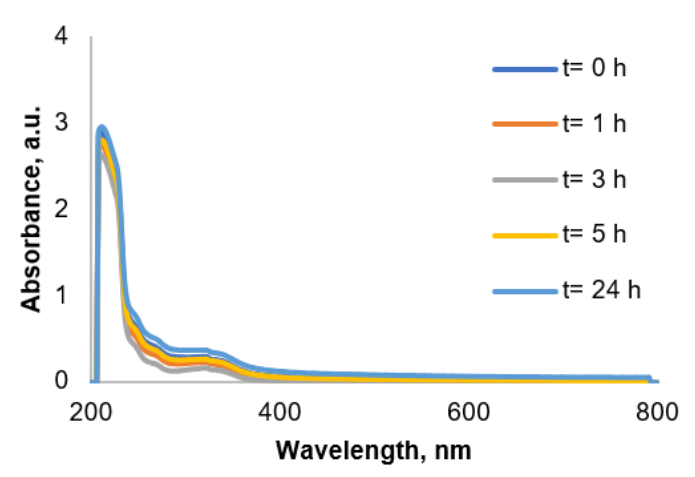

(b)

Figure 2. UV-Vis spectra of (a) $[\mathrm{Au}(\mathrm{tpy})(\mathrm{dmdtc})] \mathrm{PF}_{6}(\mathrm{C} 1)$ and $(\mathbf{b})[\mathrm{Au}(\mathrm{tpy})(\mathrm{dbdtc})] \mathrm{PF}_{6}(\mathrm{C} 5)$ for a period of $24 \mathrm{~h}$ in $\mathrm{PBS}_{\text {. }}$

Figure 2a is represented as an example of the UV-Vis spectra collected for complex C1, where the absence of new bands around $550 \mathrm{~nm}$ allowed any decomposition process to be discarded. Furthermore, no modifications were observed in either the intensity or in the shape of the bands, which highlighted the great stability of all the complexes. Something to be mentioned is the particular case of $\mathbf{C 5}$, where a slight increase in the intensity of $328 \mathrm{~nm}$ band was observed during the measured time (Figure 2b). This is usually associated with the formation of $\mathrm{Au}(\mathrm{III})-\mathrm{OH}$ bonds, increasing the water solubility and, consequently, the intensity of absorbance [60]. In biological systems, some species such as ascorbic acid (AsA) and glutathione (GSH) are present in significant concentrations, so additional studies were conducted to evaluate the susceptibility of our complexes to being reduced by these reductants. The procedure was similar to the one previously explained, but in the presence of L-glutathion reduced (GSH) and ascorbic acid (AsA). We observed that our complexes were stable with the addition of GSH over $24 \mathrm{~h}$, even in a high excess of GSH to $\mathrm{Au}(\mathrm{III})$ complexes (50 vs. $16 \mu \mathrm{M}$ ) (Figure S4), since no evidence of decomposition or new bands 
was detected. In the specific cases of $\mathbf{C} 2$ and C3, the band at $258 \mathrm{~nm}$ exhibited slight changes in intensity, but did not evolve over time. The addition of AsA did induce some significant changes in the intensity of the band centered up to $270 \mathrm{~nm}$, but corresponded to the concentration of the acid rising. Again, no new bands were registered, so the reduction of $\mathrm{Au}(\mathrm{III})$ to $\mathrm{Au}(0)$ was ruled out (Figure S5).

\subsection{Bovine Serum Albumin Interaction}

Once in the bloodstream, drugs usually bind to the present blood proteins for delivery or excretion. According to this, the influence of these proteins on the pharmacokinetic and pharmacodynamic profiles of the complexes must be studied as part of the determination of the ADMET properties. The most abundant protein present in the plasma, and the more important one for drug delivery, is albumin. Human serum albumin (HSA) regulates osmotic blood pressure; transports $\mathrm{Ca}^{2+}, \mathrm{Na}^{+}$, and $\mathrm{Zn}^{2+}$ ions; is a carrier for many hormones, fatty acids, and exogenous substances; and is a $\mathrm{pH}$ regulator [61]. Structurally, the human serum albumin protein has several domains, with secondary binding sites capable of interacting and transporting metallodrugs for their biodistribution. In order to study these bindings, HSA is normally replaced by bovine analogous (BSA) as a model protein because of its similarity, commercial availability, and better fluorescence properties [62]. Although other fluorophores are present, BSA fluorescence is mainly due to two tryptophan residues $[63,64]$.

This intrinsic fluorescence is extremely sensitive to the environment, so any binding or interaction of molecules induces changes in the BSA emission spectrum [46,47]. Consequently, interaction with BSA studies are based on monitoring the BSA luminescence in the range of $300-450 \mathrm{~nm}$ by adding increasing concentrations of $\mathrm{Au}(\mathrm{III})$ complexes (Figure 3a and Figure S6). The obtained fluorescence data were analyzed using the SternVolmer equation, which allows the Stern-Volmer quenching constant $\mathrm{K}_{\mathrm{SV}}$ and the bimolecular quenching constant $\mathrm{kq}$ to be calculated (Figure $3 \mathrm{~b}$ ). In most of the cases studied, the Stern-Volmer representation fit a straight line, indicative of a single quenching mode, either static or dynamic. In case of drug development, static quenching is usually required to probe an interaction between the drug and the protein. By studying the bimolecular quenching constant $(\mathrm{kq})$, the operated quenching can be determined since this parameter represents the efficiency of quenching or how accessible the fluorophores are to the quencher. Dynamic quenching depends on diffusion processes, so a higher kq value than the diffusion-controlled rate constant of the biomolecule in water, $10^{10} \mathrm{M}^{-1} \mathrm{~s}^{-1}$, may indicate a contribution of static quenching. All of our complexes showed values of $\mathrm{kq}$ in the order of $10^{12} \mathrm{M}^{-1} \mathrm{~s}^{-1}$ (Table 3), so static quenching could be established. Additionally, the modified Stern-Volmer equation permits the values of the binding constant $\left(\mathrm{K}_{\mathrm{b}}\right)$ for each gold complex and the number of binding sites $(n)$ to be calculated. According to the $\mathrm{K}_{\mathrm{b}}$ values observed in Table 3, there was a moderated interaction force between complex-BSA. These values were higher than other reported for gold(I) complexes $[46,47,65]$, but similar to the documented interactions for potential drugs based on ruthenium or nickel $[66,67]$. 


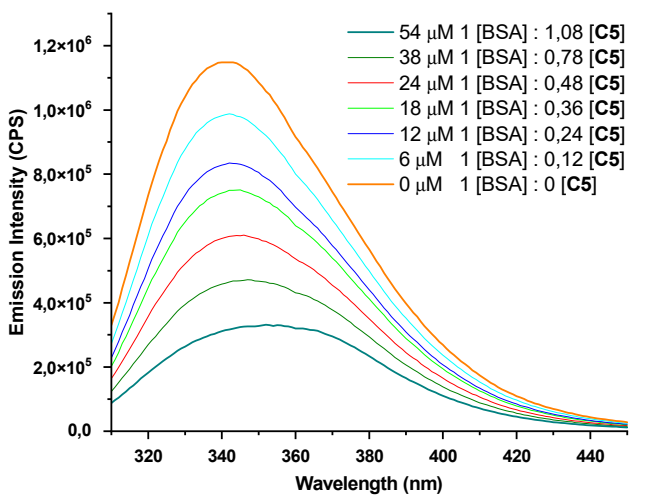

(a)

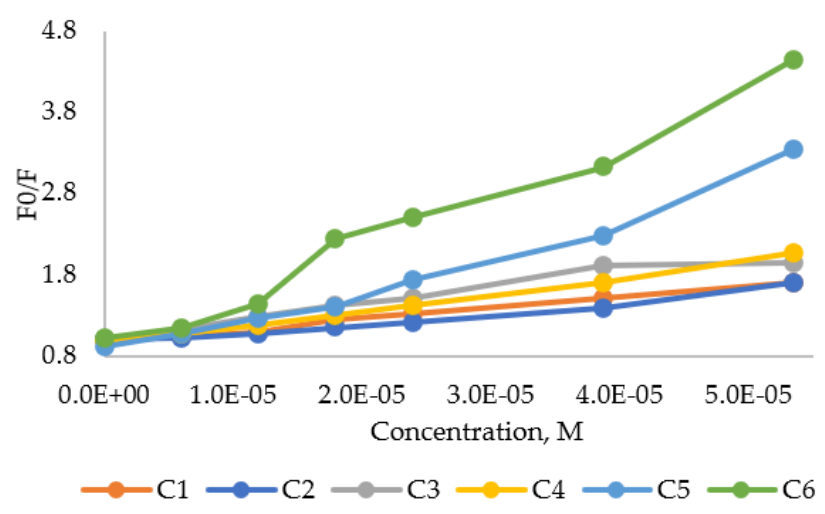

(b)

Figure 3. (a) Fluorescence emission spectra of BSA in the presence of different concentrations $(0-54 \mu \mathrm{M})$ of C4. (b) Stern-Volmer plot of synthesized gold(III) complexes.

Table 3. Values of the Stern-Volmer quenching constant $\left(\mathrm{K}_{\mathrm{SV}}\right)$, bimolecular quenching constant $(\mathrm{Kq})$, number of binding sites $(n)$ and binding constant $\left(\mathrm{K}_{\mathrm{b}}\right)$ for interacting gold(I) complexes with BSA.

\begin{tabular}{|c|c|c|c|c|}
\hline Complex & $\mathrm{K}_{\mathrm{SV}}\left(\mathbf{M}^{-1}\right)$ & $\mathrm{kq}\left(\mathrm{M}^{-1} \mathrm{~s}^{-1}\right)$ & $K_{b}\left(M^{-1}\right)$ & $n$ \\
\hline$[\mathrm{Au}(\mathrm{tpy})(\mathrm{dmdtc})] \mathrm{PF}_{6}(\mathbf{C} \mathbf{1})$ & $1.30 \times 10^{4}$ & $1.30 \times 10^{12}$ & $22.23 \times 10^{6}$ & $1.72(2)$ \\
\hline$[\mathrm{Au}(\mathrm{ppy})(\mathrm{dmdtc})] \mathrm{PF}_{6}(\mathrm{C} 2)$ & $1.37 \times 10^{4}$ & $1.37 \times 10^{12}$ & $9.70 \times 10^{5}$ & $1.42(1)$ \\
\hline$[\mathrm{Au}(\mathrm{tpy})(\mathrm{dedtc})] \mathrm{PF}_{6}(\mathbf{C} 3)$ & $1.90 \times 10^{4}$ & $1.90 \times 10^{12}$ & $1.21 \times 10^{5}$ & $0.95(1)$ \\
\hline$[\mathrm{Au}(\mathrm{ppy})($ dedtc $)] \mathrm{PF}_{6}(\mathrm{C} 4)$ & $2.01 \times 10^{4}$ & $2.01 \times 10^{12}$ & $1.23 \times 10^{5}$ & $1.18(1)$ \\
\hline$\left[\mathrm{Au}(\mathrm{tpy})(\mathrm{dbdtc}) \mathrm{PF}_{6}(\mathrm{C} 5)\right.$ & $4.43 \times 10^{4}$ & $4.43 \times 10^{12}$ & $12.61 \times 10^{6}$ & $1.57(1-2)$ \\
\hline$[\mathrm{Au}(\mathrm{ppy})(\mathrm{dbdtc})] \mathrm{PF}_{6}(\mathrm{C} \mathbf{6})$ & $6.44 \times 10^{4}$ & $6.44 \times 10^{12}$ & $5.42 \times 10^{6}$ & $1.43(1)$ \\
\hline
\end{tabular}

dmdtc: dimethyl dithiocarbamate, dedtc: diethyl dithiocarbamate, dbdtc: dibenzyl dithiocarbamate.

Therefore, our complexes can be transported by BSA protein throughout the body, one molecule each of BSA according to the results of $n$ parameter (except for $\mathbf{C 1}$ or $\mathbf{C 5}$, where two molecules of gold complex could be found in the same BSA structure).

\subsection{In Vitro Antiproliferative Activity}

The in vitro cytotoxic effect was evaluated on human colon cancer cell line Caco2/TC7. This particular cell line presents a huge advantage for toxicity studies because of its spontaneous enterocytic-like differentiation when confluence is reached. Therefore, Caco-2 cells become polarized cells expressing apical and basolateral surfaces with well-established tight junctions [68-70]. Thus, cells present noncarcinogenic behavior in the confluence and the cytotoxic effect of our complexes can be performed on differentiated cells to evaluate the selectivity toward tumor cells. For the antiproliferative studies, MTT assay was performed after $72 \mathrm{~h}$ of exposure to different concentrations of the complexes at two different stages of confluence, five days to evaluate the effect on tumor cells (Figure S7) and 15 days for normal cells (Figure S8). As can be observed in Table 4, great results were accomplished since most of our complexes showed a higher antiproliferative effect on tumor cells than cisplatin $\left(\mathrm{IC}_{50}=45.60 \pm 8.08 \mu \mathrm{M}\right)$, auranofin $\left(\mathrm{IC}_{50}=2.10 \pm 0.40 \mu \mathrm{M}\right)$ [27], and some other dithiocarbamates reported on [27]. The DTC group seemed to play a crucial role in the complexes to exhibit this cytotoxicity, as the cyclometalated precursors did not alter Caco-2 normal or tumor cell viability [17]. However, something to be remarkable is that our complexes exhibited excellent selectivity, 4.5-8.8-fold higher for tumor than normal cells, and especially complex $\mathbf{C} 5$, which seemed to not alter cell proliferation of normal cells up to $100 \mu \mathrm{M}$, with a selectivity at least 48.3 times higher for cancer cells. This fact highlights the potential application of our complexes in the chemotherapy field. 
Table 4. $\mathrm{IC}_{50}$ values $(\mu \mathrm{M})$ of the gold(III) complexes against Caco-2/TC7 cells.

\begin{tabular}{|c|c|c|c|}
\hline Complex & Tumor Cells & Normal Cells & $\begin{array}{l}\text { Tumor Cells Selectivity } \\
\text { over Normal Cells }\end{array}$ \\
\hline$\left[\mathrm{Au}(\mathrm{tpy}) \mathrm{Cl}_{2}\right]^{1}$ & NS & NS & - \\
\hline$\left[\mathrm{Au}(\text { ppy }) \mathrm{Cl}_{2}\right]^{1}$ & NS & NS & - \\
\hline$[\mathrm{Au}(\mathrm{tpy})(\mathrm{dmdtc})] \mathrm{PF}_{6}(\mathbf{C} \mathbf{1})$ & $5.11 \pm 0.12$ & $23.03 \pm 0.06$ & 4.5-fold \\
\hline$[\mathrm{Au}(\mathrm{ppy})(\mathrm{dmdtc})] \mathrm{PF}_{6}(\mathrm{C} 2)$ & $1.79 \pm 0.12$ & $15.69 \pm 0.06$ & 8.8-fold \\
\hline$[\mathrm{Au}($ tpy $)($ dedtc $)] \mathrm{PF}_{6}(\mathrm{C} 3)$ & $1.85 \pm 0.36$ & $12.95 \pm 0.11$ & 7.0-fold \\
\hline$\left[\mathrm{Au}(\mathrm{ppy})(\right.$ dedtc $) \mathrm{PF}_{6}(\mathrm{C} 4)$ & $2.47 \pm 0.25$ & $16.79 \pm 0.13$ & 6.8-fold \\
\hline$[\mathrm{Au}(\mathrm{tpy})(\mathrm{dbdtc})] \mathrm{PF}_{6}(\mathrm{C} 5)$ & $2.07 \pm 0.11$ & $>>100$ & $>>48.3$-fold \\
\hline$[\mathrm{Au}(\mathrm{ppy})(\mathrm{dbdtc})] \mathrm{PF}_{6}(\mathrm{C} \mathbf{6})$ & $4.02 \pm 0.30$ & $24.74 \pm 0.36$ & 6.2-fold \\
\hline
\end{tabular}

${ }^{1}$ Ref. [12]. All the results are expressed as mean $\pm \log$ SEM $(n \geq 12$ experiments) after $72 \mathrm{~h}$ of incubation. (-) Not applicable.

\subsection{Apoptosis Studies}

After obtaining great results from the cell viability studies, it was determined that only non-cytotoxic complexes on normal cells are good candidates as anticancer drugs, so complexes $\mathbf{C 1}, \mathbf{C 5}$, and $\mathbf{C 6}$ were selected for the following studies. Thus, we proceeded to elucidate the action mechanism of these three complexes to induce cell death. The most convenient cell death for anticancer drugs is apoptosis, since in this way no inflammation processes occur and it is carefully controlled. The apoptotic way is normally characterized by several morphological changes in the cell membrane, by which phosphatidylserine (PS) is exposed, moving from the inner part to the outer surface of the membrane [71,72]. Thanks to this translocation, Annexin V (FITC-conjugated) can interact selectively with the PS, differentiating healthy cells from apoptotic cells. Besides, cells undergoing late apoptosis stages and necrotic cells present deep damage in the membrane that makes 7-aminoactinomycin D (7-AAD) access the nucleus. Therefore, by using flow cytometry, all different cell populations can be distinguished. In this study, no significant differences in the percentage of cells in apoptosis were detected between control and treated cell populations. According to our results, the cells did not die because of necrosis, either (Figure 4 and Figure S9).

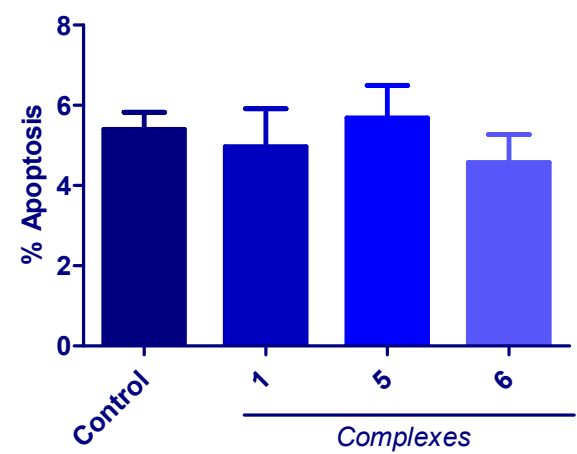

(a)

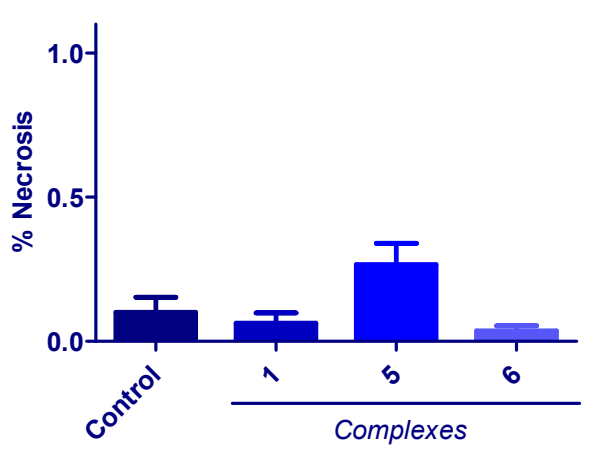

(b)

Figure 4. Undifferentiated Caco-2/TC7 cell apoptotic-state (a) and necrotic-state (b) analysis after 24 $\mathrm{h}$ of incubation with $\mathbf{C 1}, \mathbf{C} 5$, and $\mathbf{C 6}(20 \mu \mathrm{M})$.

\subsection{Cell-Cycle Studies}

Tumor cells grow and proliferate faster than normal cells, indicating that normal cellcycle progression has been disrupted. To stop the uncontrolled replication of tumor cells is still one of the main aims in the chemotherapy field; thus, arresting the tumor cell cycle in as many stages as possible is considered crucial. Current metallodrugs such as cisplatin or oxaliplatin show arrest of the G2/M phase [73,74], thanks to which the reproduction of tumor cells is inhibited. As is known, the geometry and structure of the complex have 
a great impact on the action mechanism of the drug, so there are examples of gold(III) complexes that alter the cell cycle at the G0/G1 phase [75], but also others at G2/M phase [76]. Our studies of the DNA content in Caco-2 cells stained with propidium iodide by flow cytometry showed that the major part of the cell population was in the G0/G1 phase after treatment with complexes $\mathbf{C 1}, \mathbf{C 5}$, or $\mathbf{C 6}$. Additionally, these complexes did not have a significant impact on the normal development of the cell cycle, as the number of cells in G2/M or S phases was similar to control (Figure 5 and Figure S10).

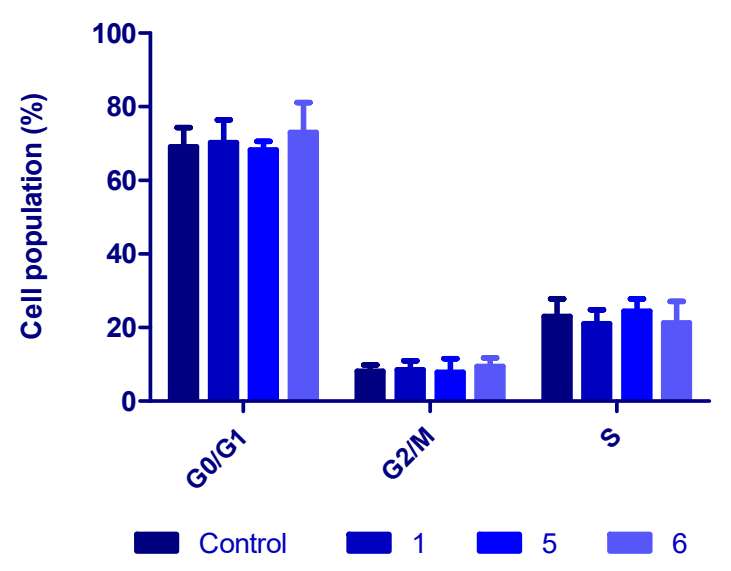

Figure 5. Cell population (\%) in each stage of the cell cycle obtained by flow cytometry after $24 \mathrm{~h}$ of incubation of the cells with DMSO (control) and gold(III) complexes 1, 5, and $6(20 \mu \mathrm{M})$.

\subsection{Oxidative Stress Damage}

According to the literature, gold complexes act as anticancer agents by the disruption of redox homeostasis. As a result, the concentration of ROS species rises and consequently, main biomolecules, such as lipids, proteins, or even DNA, can be oxidized. However, tumor cells present an overproduction of ROS species due to their high metabolism [77]. The most common anticancer strategy is promoting a higher oxidative damage in biomolecules to trigger the apoptosis process [78]. However, there are some examples where a relationship between antioxidant and antitumor behavior has been demonstrated [79,80], even with gold(III) complexes $[54,81,82]$. In this study, we evaluated the oxidation levels of the carbonyl groups present in proteins by the established method of 2,4-dinitrophenylhydrazine (DNPH) [83]. The results in Figure 6 show that our three complexes significantly decreased the oxidized protein levels, indicating that our complexes behave as antioxidant agents.

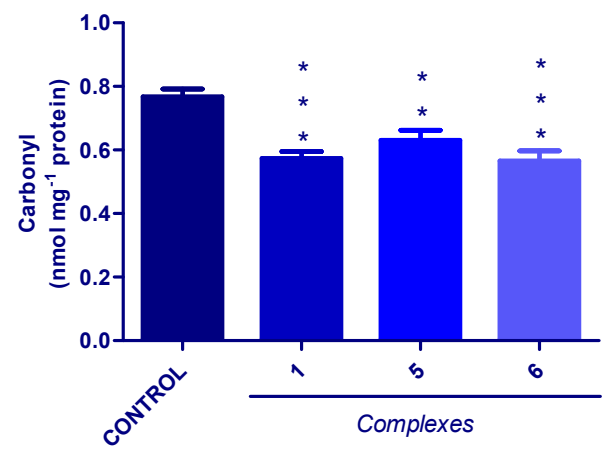

Figure 6. Carbonyl levels (nmol mg ${ }^{-1}$ protein) in Caco-2/TC7 cells treated with vehicle DMSO (control) or gold(III) complexes $(24 \mathrm{~h}, 20 \mu \mathrm{M})$. Values are expressed as mean values $\pm \operatorname{SEM}(n \geq 6$ experiments). ${ }^{* *} p<0.01 ;{ }^{* * *} p<0.001$ vs. control.

Since no evidence of apoptotic (via PS exposure) or necrotic cells was detected in previous studies on cell-death mechanism, other cell-death pathways can be considered related to oxidative stress processes. Among them, autophagy is gaining attention in 
the chemotherapy field. Autophagy can present both negative and positive effects in cancer since autophagy inhibition can lead to tumor cell death or hyperproliferation [84]. According to previous studies, autophagy cell death is induced by stress signals, such as increased ROS, hypoxia, and mitochondrial damage $[85,86]$. However, based on our results, the selected gold complexes $(\mathbf{C 1}, \mathbf{C} 5$, and $\mathbf{C 6})$ did not promote oxidative stress damage, so our complexes do not seem to be potential autophagy promoters.

\subsection{Antimicrobial Activity}

Recently, the emergence of resistance to antimicrobial drugs and the toxicity of antimicrobials makes the development of new drugs necessary. For this purpose, all complexes were tested in five different pathogenic bacteria, including methicillin-resistant Staphylococcus aureus, Escherichia coli, Klebsiella pneumonia, Psedomonas aeruginosa, Acinetobacter baumannii, and two different fungi, Candida albicans and Cryptococcus neoformans. The obtained results for these studies, expressed as minimum inhibitory concentrations for microorganisms (MICs), are collected in Table 5. All the gold complexes showed antimicrobial activity, but C1-4 complexes in particular showed MIC values of $0.25 \mu \mathrm{g} / \mathrm{mL}$ for methicillinresistant $S$. aureus. Really low MICs, compared to those reported in other studies, of values from 2 to $15 \mu \mathrm{g} / \mathrm{mL}$ were obtained against this S. aureus strain $[87,88]$, a bacterium that causes a range of illnesses, from minor skin infections, to life-threatening diseases such as pneumonia, meningitis, endocarditis, toxic shock syndrome, and sepsis. C1-4 complexes were also shown to be effective against $E$. coli, a bacteria that can induce infections of the gastrointestinal and urinary tracts. Although the MIC values of $32 \mu \mathrm{g} / \mathrm{mL}$ obtained against the E. coli strain were significantly higher than those obtained against Sa, they can still be considered great results since other similar gold(III) complexes did not inhibit the growth of the E. coli strain $(\leq 125 \mathrm{mg} / \mathrm{mL})$ or other Gram-negative bacteria such as $K$. pneumonia, p. aeruginosa, or Acinetobacter baumannii $[89,90]$. Although $S$. aureus was the only Gram-positive bacteria tested, it seemed that our complexes were more effective against Gram-positive than Gram-negative bacteria. This effect was also observed in other gold complexes previously reported, [91,92]. Again, the importance of the structure on the final properties was evident, since only one $\mathrm{CH}_{2}$-bridge in the ancillary ligand or moving from the catecholate to dithiocarbamate group inverted the selectivity to Gram-negative [93]. The antifungal activity was also found to be acceptable, especially for complex C6, with really low MIC values against $C$. albicans $(4 \mu \mathrm{g} / \mathrm{mL})$ and $C$. neoformans $(\leq 0,25 \mu \mathrm{g} / \mathrm{mL})$, and complex $\mathrm{C} 3$ against $C$. neoformans $(4 \mu \mathrm{g} / \mathrm{mL})$. The results for the fungi strains are also quite promising compared to those of other previous studies [94,95]. The SAR effect was also revealed, as $\mathbf{C} 4$ and $\mathbf{C} \mathbf{6}$ differed only in the methyl group of the pyridine ancillary ligand and their activity against $C$. albicans varied from 4 to $32 \mu \mathrm{g} / \mathrm{mL}$.

Table 5. MIC values of gold(III) complexes against methicillin-resistant Staphylococcus aureus (Sa), Escherichia coli (Ec), Klebsiella pneumonia (Kp), Psedomonas aeruginosa (Pa), Acinetobacter baumannii (Ab), Candida albicans (Ca), and Cryptococcus neoformans (Cn).

\begin{tabular}{|c|c|c|c|c|c|c|c|}
\hline \multirow[b]{2}{*}{ Complex } & \multicolumn{7}{|c|}{ MIC ( $\mu \mathrm{g} / \mathrm{mL})$} \\
\hline & Sa & Ec & Kp & $\mathbf{P a}$ & $\mathrm{Ab}$ & $\mathrm{Ca}$ & Cn \\
\hline$[\mathrm{Au}(\mathrm{tpy})(\mathrm{dmdtc})] \mathrm{PF}_{6}(\mathbf{C} \mathbf{1})$ & $\leq 0.25$ & 32 & $>32$ & $>32$ & $>32$ & $>32$ & 32 \\
\hline$[\mathrm{Au}(\mathrm{ppy})(\mathrm{dmdtc})] \mathrm{PF}_{6}(\mathrm{C} 2)$ & $\leq 0.25$ & 32 & $>32$ & $>32$ & 32 & 32 & 32 \\
\hline$[\mathrm{Au}(\mathrm{tpy})($ dedtc $)] \mathrm{PF}_{6}(\mathrm{C} 3)$ & $\leq 0.25$ & 32 & $>32$ & $>32$ & $>32$ & $>32$ & 2 \\
\hline$\left[\mathrm{Au}(\mathrm{ppy})(\right.$ dedtc) $] \mathrm{PF}_{6}(\mathrm{C} 4)$ & $\leq 0.25$ & 32 & $>32$ & $>32$ & $>32$ & 32 & 32 \\
\hline$[\mathrm{Au}(\mathrm{tpy})(\mathrm{dbdtc})] \mathrm{PF}_{6}(\mathrm{C} 5)$ & 32 & $>32$ & $>32$ & $>32$ & $>32$ & 32 & 32 \\
\hline$[\mathrm{Au}(\mathrm{ppy})(\mathrm{dbdtc})] \mathrm{PF}_{6}(\mathbf{C} \mathbf{6})$ & 4 & $>32$ & $>32$ & $>32$ & 32 & 4 & $\leq 0.25$ \\
\hline
\end{tabular}

\section{Conclusions}

In this study, we report on the synthesis of new cyclometalated gold(III) complexes with dithiocarbamate moiety. The ability of dithiocarbamate complexes to access the inside of the cell was evaluated by the measure of the partition coefficient, with our complexes 
showing great values consequent with good biodistribution. Besides, all of them were perfectly stable in a physiological environment, according to the results of the UV-Vis studies, and no decomposition or redox process was observed. Their interaction with BSA was found to be moderate, suggesting protein-assisted transport through the blood and easy target release. All these derivatives displayed a high antiproliferative effect and excellent selectivity on Caco-2 human colon cancer cells, including one of the complexes $[\mathrm{Au}(\mathrm{tpy})(\mathrm{dbdtc})]$ not altering the normal cell proliferation up to $100 \mu \mathrm{M}$, so its selectivity was at least 48.3-fold high for cancer cells. This fact reveals the enormous impact of a single methyl group on permeability and, consequently, on the action mechanism. Despite this great antiproliferative activity, these complexes did not exhibit any tumor cell-cycle arrest like other dithiocarbamate complexes, although they acted as antioxidant agents. Therefore, additional studies are needed to elucidate the action mechanism more accurately. Additionally, antimicrobial tests were also conducted and showed promising properties, since all complexes exhibited an excellent antibacterial effect against $S$. aureus and a good effect against $E$. coli. The antifungal activity was also found to be acceptable, especially for complex C6, with really low MIC values against $C$. albicans and C. neoformans.

Supplementary Materials: The following is available online at https:/ / www.mdpi.com/article/ 10.3390/biomedicines9121775/s1, Figure S1. 1H-NMR spectra of complexes C1-6 and APT spectra for C3, C5-C6. Figure S2: Comparison of the theoretical and experimental MS spectra of complexes $\mathrm{C} 2, \mathrm{C} 3$, and $\mathrm{C} 6$ (from left to right). Figure S3: UV-Vis spectra of complexes C1-6 recorded at different times for $24 \mathrm{~h}$ in PBS at $37^{\circ} \mathrm{C}$. Figure S4: UV-Vis spectra of complexes $\mathrm{C} 1-6$ recorded at different times for $24 \mathrm{~h}$ in PBS at $37^{\circ} \mathrm{C}$ in the presence of GSH $(0-50 \mu \mathrm{M})$. Figure S5: UV-Vis spectra of complexes C1-6 recorded at different times for $24 \mathrm{~h}$ in PBS at $37^{\circ} \mathrm{C}$ in the presence of AsA $(0-20 \mu \mathrm{M})$. Figure S6: Fluorescence emission spectra of BSA at $298 \mathrm{~K}$ in the presence of increasing amounts of the gold(III) complexes. Figure S7: Cell viability of tumor Caco-2 cells ( 5 days after seeding) treated with C1-6 gold(III) complexes for $72 \mathrm{~h}$. Figure S8: Cell viability of normal Caco-2 cells (15 days after seeding) treated with C1-6 gold(III) complexes for $72 \mathrm{~h}$. Figure S9: Fluorescence histograms of the distribution of cell populations in different stages: necrosis (B+-), living cells (B--), late apoptosis (B++), and early apoptosis (B+-) in control (DMSO) and gold(III) complex-treated (20 $\mu \mathrm{M}, 24 \mathrm{~h}$ ) Caco-2/TC7 cells. Figure S10: Fluorescence histograms obtained by flow cytometry of the cell populations in different phases of the cell cycle after $24 \mathrm{~h}$ of incubation of the cells with DMSO (control) and gold(III) complexes 1 and 5-6 (20 $\mu \mathrm{M})$.

Author Contributions: M.L. and L.G. conceived the original idea and supervised the project. E.A. conducted the synthetic part. E.A. and D.A.-R. carried out the experiments and analyzed the data. E.A., L.G., and M.L. wrote the manuscript. All authors have read and agreed to the published version of the manuscript.

Funding: This research was partially funded by Gobierno de Aragón (Grupo Reconocido A20_20R) and associated with the EU Regional Development Fund. The antimicrobial screening performed by CO-ADD (The Community for Antimicrobial Drug Discovery) was funded by the Wellcome Trust (UK) and The University of Queensland (Australia).

Institutional Review Board Statement: Not applicable.

Informed Consent Statement: Not applicable.

Data Availability Statement: The authors confirm that the data supporting the findings of this study are available within the article and its supplementary materials.

Acknowledgments: We are grateful to José Emilio Mesonero (Departamento de Farmacología, Fisiología y Medicina Legal y Forense, Universidad de Zaragoza, Spain) for providing the Caco2/TC7 cell line. The authors thank Centro de Investigación Biomédica de Aragón (CIBA) and Servicios científico-técnicos del ISQCH for the technical assistance, and Torrecid S.A. for the generous donation of $\mathrm{HAuCl}_{4}$.

Conflicts of Interest: The authors declare no conflict of interest. 


\section{References}

1. Gómez-Ruiz, S.; Maksimović-Ivanić, D.; Mijatović, S.; Kaluđerović, G.N. On the discovery, biological effects, and use of Cisplatin and metallocenes in anticancer chemotherapy. Bioinorg. Chem. Appl. 2012, 2012, 140284. [CrossRef] [PubMed]

2. Ghosh, S. Cisplatin: The first metal based anticancer drug. Bioorgan. Chem. 2019, 88, 102925. [CrossRef] [PubMed]

3. Oun, R.; Moussa, Y.E.; Wheate, N.J. The side effects of platinum-based chemotherapy drugs: A review for chemists. Dalton Trans. 2018, 47, 6645-6653. [CrossRef] [PubMed]

4. Guo, Z.; Sadler, P.J. Metals in Medicine. Angew. Chem. Int. Ed. 1999, 38, 1512-1531. [CrossRef]

5. Xie, L.; Luo, Z.; Zhao, Z.; Chen, T. Anticancer and Antiangiogenic Iron(II) Complexes That Target Thioredoxin Reductase to Trigger Cancer Cell Apoptosis. J. Med. Chem. 2017, 60, 202-214. [CrossRef] [PubMed]

6. Kallus, S.; Uhlik, L.; van Schoonhoven, S.; Pelivan, K.; Berger, W.; Enyedy, É.A.; Hofmann, T.; Heffeter, P.; Kowol, C.R.; Keppler, B.K. Synthesis and biological evaluation of biotin-conjugated anticancer thiosemicarbazones and their iron(III) and copper(II) complexes. J. Inorg. Biochem. 2019, 190, 85-97. [CrossRef]

7. Riccardi, C.; Musumeci, D.; Trifuoggi, M.; Irace, C.; Paduano, L.; Montesarchio, D. Anticancer Ruthenium(III) Complexes and $\mathrm{Ru}(\mathrm{III})$-Containing Nanoformulations: An Update on the Mechanism of Action and Biological Activity. Pharmaceuticals 2019, 12, 146. [CrossRef]

8. Lazarević, T.; Rilak, A.; Bugarčić, Ž.D. Platinum, palladium, gold and ruthenium complexes as anticancer agents: Current clinical uses, cytotoxicity studies and future perspectives. Eur. J. Med. Chem. 2017, 142, 8-31. [CrossRef]

9. Mendoza, Z.; Lorenzo-Luis, P.; Scalambra, F.; Padrón, J.M.; Romerosa, A. One Step Up in Antiproliferative Activity: The Ru-Zn Complex [RuCp $\left(\mathrm{PPh}_{3}\right)_{2}-\mu$-dmoPTA-1kP:2k2 $\left.\mathrm{N}, \mathrm{N}^{\prime}-\mathrm{ZnCl}_{2}\right]\left(\mathrm{CF}_{3} \mathrm{SO}_{3}\right)$. Eur. J. Inorg. Chem. 2018, 2018, 4684-4688. [CrossRef]

10. Milacic, V.; Fregona, D.; Dou, Q.P. Gold complexes as prospective metal-based anticancer drugs. Histol. Histopathol. 2008, 23, 101-108. [CrossRef]

11. Nobili, S.; Mini, E.; Landini, I.; Gabbiani, C.; Casini, A.; Messori, L. Gold compounds as anticancer agents: Chemistry, cellular pharmacology, and preclinical studies. Med. Res. Rev. 2010, 30, 550-580. [CrossRef]

12. Omondi, R.O.; Ojwach, S.O.; Jaganyi, D. Review of comparative studies of cytotoxic activities of $\mathrm{Pt}(\mathrm{II}), \mathrm{Pd}(\mathrm{II}), \mathrm{Ru}(\mathrm{II}) /(\mathrm{III}) \mathrm{and}$ $\mathrm{Au}(\mathrm{III})$ complexes, their kinetics of ligand substitution reactions and DNA/BSA interactions. Inorg. Chim. Acta 2020, 512, 119883. [CrossRef]

13. Murray, B.S.; Dyson, P.J. Recent progress in the development of organometallics for the treatment of cancer. Curr. Opin. Chem. Biol. 2020, 56, 28-34. [CrossRef]

14. Roder, C.; Thomson, M.J. Auranofin: Repurposing an Old Drug for a Golden New Age. Drugs R D 2015, 15, 13-20. [CrossRef]

15. Shaw, C.F. Gold-Based Therapeutic Agents. Chem. Rev. 1999, 99, 2589-2600. [CrossRef]

16. Tiekink, E.R.T. Anti-cancer potential of gold complexes. Inflammopharmacology 2008, 16, 138-142. [CrossRef] [PubMed]

17. Abás, E.; Gómez-Bachiller, M.; Colom, E.; Pardina, E.; Rodríguez-Diéguez, A.; Grasa, L.; Laguna, M. Cyclometallated gold(III) complexes against colon cancer. X-ray structure of [Au(C,NPhenylpyridine)(OAc)2]. J. Organomet. Chem. 2020, 920, 121340. [CrossRef]

18. Henderson, W.; Nicholson, B.K.; Faville, S.J.; Fan, D.; Ranford, J.D. Gold(III) thiosalicylate complexes containing cycloaurated 2-arylpyridine, 2-anilinopyridine and 2-benzylpyridine ligands. J. Organomet. Chem. 2001, 631, 41-46. [CrossRef]

19. Ronconi, L.; Marzano, C.; Zanello, P.; Corsini, M.; Miolo, G.; Maccà, C.; Trevisan, A.; Fregona, D. Gold(III) Dithiocarbamate Derivatives for the Treatment of Cancer: Solution Chemistry, DNA Binding, and Hemolytic Properties. J. Med. Chem. 2006, 49, 1648-1657. [CrossRef]

20. Smith, T.S.; Henderson, W.; Nicholson, B.K. Cycloaurated gold(III) complexes with monoanionic thiourea ligands. Inorg. Chim. Acta 2013, 408, 27-32. [CrossRef]

21. Zou, T.; Lum, C.T.; Lok, C.-N.; Zhang, J.-J.; Che, C.-M. Chemical biology of anticancer gold(iii) and gold(i) complexes. Chem. Soc. Rev. 2015, 44, 8786-8801. [CrossRef] [PubMed]

22. Boscutti, G.; Nardon, C.; Marchiò, L.; Crisma, M.; Biondi, B.; Dalzoppo, D.; Dalla Via, L.; Formaggio, F.; Casini, A.; Fregona, D. Anticancer Gold(III) Peptidomimetics: From Synthesis to in vitro and ex vivo Biological Evaluations. ChemMedChem 2018, 13, 1131-1145. [CrossRef] [PubMed]

23. Saggioro, D.; Rigobello, M.P.; Paloschi, L.; Folda, A.; Moggach, S.A.; Parsons, S.; Ronconi, L.; Fregona, D.; Bindoli, A. Gold(III)Dithiocarbamato Complexes Induce Cancer Cell Death Triggered by Thioredoxin Redox System Inhibition and Activation of ERK Pathway. Chem. Biol. 2007, 14, 1128-1139. [CrossRef] [PubMed]

24. Williams, M.R.M.; Bertrand, B.; Hughes, D.L.; Waller, Z.A.E.; Schmidt, C.; Ott, I.; O'Connell, M.; Searcey, M.; Bochmann, M. Cyclometallated $\mathrm{Au}(\mathrm{iii})$ dithiocarbamate complexes: Synthesis, anticancer evaluation and mechanistic studies. Metallomics 2018, 10, 1655-1666. [CrossRef]

25. Nardon, C.; Boscutti, G.; Gabbiani, C.; Massai, L.; Pettenuzzo, N.; Fassina, A.; Messori, L.; Fregona, D. Cell and Cell-Free Mechanistic Studies on Two Gold(III) Complexes with Proven Antitumor Properties. Eur. J. Inorg. Chem. 2017, $2017,1737-1744$. [CrossRef]

26. Nardon, C.; Fregona, D. Gold(III) Complexes in the Oncological Preclinical Arena: From Aminoderivatives to Peptidomimetics. Curr. Top. Med. Chem. 2016, 16, 360-380. [CrossRef] 
27. Quero, J.; Cabello, S.; Fuertes, T.; Mármol, I.; Laplaza, R.; Polo, V.; Gimeno, M.C.; Rodriguez-Yoldi, M.J.; Cerrada, E. Proteasome versus Thioredoxin Reductase Competition as Possible Biological Targets in Antitumor Mixed Thiolate-Dithiocarbamate Gold(III) Complexes. Inorg. Chem. 2018, 57, 10832-10845. [CrossRef]

28. Aldin, M.Z.; Zaragoza, G.; Delaude, L. Synthesis of ruthenium-dithiocarbamate chelates bearing diphosphine ligands and their use as latent initiators for atom transfer radical additions. J. Organomet. Chem. 2021, 950, 121993. [CrossRef]

29. Ekennia, A.C.; Onwudiwe, D.C.; Osowole, A.A. Spectral, thermal stability and antibacterial studies of copper, nickel and cobalt complexes of N-methyl-N-phenyl dithiocarbamate. J. Sulfur Chem. 2015, 36, 96-104. [CrossRef]

30. Scintilla, S.; Brustolin, L.; Gambalunga, A.; Chiara, F.; Trevisan, A.; Nardon, C.; Fregona, D. Ru(III) anticancer agents with aromatic and non-aromatic dithiocarbamates as ligands: Loading into nanocarriers and preliminary biological studies. J. Inorg. Biochem. 2016, 165, 159-169. [CrossRef]

31. Tan, Y.S.; Yeo, C.I.; Tiekink, E.R.T.; Heard, P.J. Dithiocarbamate Complexes of Platinum Group Metals: Structural Aspects and Applications. Inorganics 2021, 9, 60. [CrossRef]

32. Blaskovich, M.A.; Zuegg, J.; Elliott, A.G.; Cooper, M.A. Helping Chemists Discover New Antibiotics. ACS Infect. Dis. 2015, 1, 285-287. [CrossRef]

33. Chang, E.L.; Simmers, C.; Knight, D.A. Cobalt Complexes as Antiviral and Antibacterial Agents. Pharmaceuticals 2010, 3 , 1711-1728. [CrossRef] [PubMed]

34. Harrison, J.J.; Turner, R.J.; Joo, D.A.; Stan, M.A.; Chan, C.S.; Allan, N.D.; Vrionis, H.A.; Olson, M.E.; Ceri, H. Copper and Quaternary Ammonium Cations Exert Synergistic Bactericidal and Antibiofilm Activity against Pseudomonas aeruginosa. Antimicrob. Agents Chemother. 2008, 52, 2870-2881. [CrossRef] [PubMed]

35. Sim, W.; Barnard, R.T.; Blaskovich, M.A.T.; Ziora, Z.M. Antimicrobial Silver in Medicinal and Consumer Applications: A Patent Review of the Past Decade (2007-2017). Antibiotics 2018, 7, 93. [CrossRef] [PubMed]

36. Storr, T.; Thompson, K.H.; Orvig, C. Design of targeting ligands in medicinal inorganic chemistry. Chem. Soc. Rev. 2006, 35, 534-544. [CrossRef]

37. Constable, E.C.; Leese, T.A. Cycloaurated derivatives of 2-phenylpyridine. J. Organomet. Chem. 1989, 363, 419-424. [CrossRef]

38. Janzen, D.E.; Doherty, S.R.; VanDerveer, D.G.; Hinkle, L.M.; Benefield, D.A.; Vashi, H.M.; Grant, G.J. Cyclometallated gold(III) complexes with a trithiacrown ligand: Solventless $\mathrm{Au}(\mathrm{III})$ cyclometallation, intramolecular gold-sulfur interactions, and fluxional behavior in 1,4,7-trithiacyclononane Au(III) complexes. J. Organomet. Chem. 2014, 755, 47-57. [CrossRef]

39. Parish, R.V.; Wright, J.P.; Pritchard, R.G. Mercury(II) and gold(III) derivatives of 2-phenyl pyridines and 2-phenyl-4(methylcarboxylato)quinoline. J. Organomet. Chem. 2000, 596, 165-176. [CrossRef]

40. Kerns, E.H.; Di, L. Lipophilicity Methods, Drug-like Properties: Concepts, Structure Design and Methods. In Lipophilicity Methods; Elsevier: San Diego, CA, USA, 2008; p. 10.

41. Wein, A.N.; Stockhausen, A.T.; Hardcastle, K.I.; Saadein, M.R.; Peng, S.; Wang, D.; Shin, D.M.; Chen, Z.; Eichler, J.F. Tumor cytotoxicity of 5,6-dimethyl-1,10-phenanthroline and its corresponding gold(III) complex. J. Inorg. Biochem. 2011, 105, 663-668. [CrossRef]

42. Mote, U.S.; Bhattar, S.L.; Patil, S.R.; Kolekar, G.B. Interaction between felodipine and bovine serum albumin: Fluorescence quenching study. Lumin. J. Biol. Chem. Lumin. 2010, 25, 1-8. [CrossRef]

43. Szymańska, M.; Pospieszna-Markiewicz, I.; Mańka, M.; Insińska-Rak, M.; Dutkiewicz, G.; Patroniak, V.; Fik-Jaskółka, M.A. Synthesis and Spectroscopic Investigations of Schiff Base Ligand and Its Bimetallic Ag(I) Complex as DNA and BSA Binders. Biomolecules 2021, 11, 1449. [CrossRef]

44. Mesonero, J.; Mahraoui, L.; Matosin, M.; Rodolosse, A.; Rousset, M.; Brot-Laroche, E. Expression of the hexose transporters GLUT1-GLUT5 and SGLT1 in clones of Caco-2 cells. Biochem. Soc. Trans. 1994, 22, 681-684. [CrossRef] [PubMed]

45. Zucco, F.; Batto, A.F.; Bises, G.; Chambaz, J.; Chiusolo, A.; Consalvo, R.; Cross, H.; Dal Negro, G.; de Angelis, I.; Fabre, G.; et al. An inter-laboratory study to evaluate the effects of medium composition on the differentiation and barrier function of Caco-2 cell lines. Altern. Lab. Anim. 2005, 33, 603-618. [CrossRef] [PubMed]

46. Abas, E.; Espallargas, N.; Burbello, G.; Mesonero, J.E.; Rodriguez-Dieguez, A.; Grasa, L.; Laguna, M. Anticancer Activity of Alkynylgold(I) with P(NMe2)3 Phosphane in Mouse Colon Tumors and Human Colon Carcinoma Caco-2 Cell Line. Inorg. Chem. 2019, 58, 15536-15551. [CrossRef] [PubMed]

47. Abas, E.; Pena-Martinez, R.; Aguirre-Ramírez, D.; Rodriguez-Dieguez, A.; Laguna, M.; Grasa, L. New selective thiolate gold(i) complexes inhibit the proliferation of different human cancer cells and induce apoptosis in primary cultures of mouse colon tumors. Dalton Trans. 2020, 49, 1915-1927. [CrossRef]

48. Mosmann, T. Rapid colorimetric assay for cellular growth and survival: Application to proliferation and cytotoxicity assays. J. Immunol. Methods 1983, 65, 55-63. [CrossRef]

49. Gonzalo, S.; Grasa, L.; Arruebo, M.P.; Plaza, M.Á.; Murillo, M.D. Extracellular signal-regulated kinase (ERK) is involved in LPS-induced disturbances in intestinal motility. Neurogastroenterol. Motil. 2011, 23, e80-e90. [CrossRef]

50. Brown, S.D.J.; Henderson, W.; Kilpin, K.J.; Nicholson, B.K. Orthomercurated and cycloaurated derivatives of the iminophosphorane Ph3PNPh. Inorg. Chim. Acta 2007, 360, 1310-1315. [CrossRef]

51. Vicente, J.; Chicote, M.T.; Bermúdez, M.D. 2-[(Dimethylamino)methyl]phenylgold(III) complexes. J. Organomet. Chem. 1984, 268, 191-195. [CrossRef] 
52. Cinellu, M.A.; Zucca, A.; Stoccoro, S.; Minghetti, G.; Manassero, M.; Sansoni, M. Synthesis and characterization of gold(III) adducts and cyclometallated derivatives with 2-substituted pyridines. Crystal structure of [Au\{ $\mathrm{NC} 5 \mathrm{H} 4(\mathrm{CMe} 2 \mathrm{C} 6 \mathrm{H} 4)-2\} \mathrm{Cl} 2]$. J. Chem. Soc. Dalton Trans. 1995, 2865-2872. [CrossRef]

53. Fuchita, Y.; Ieda, H.; Wada, S.; Kameda, S.; Mikuriya, M. Organogold(III) complexes derived from auration reactions of thienylsubstituted pyridine derivatives. J. Chem. Soc. Dalton Trans. 1999, 4431-4435. [CrossRef]

54. Khan, E.; Khan, U.A.; Badshah, A.; Tahir, M.N.; Altaf, A.A. Supramolecular dithiocarbamatogold(III) complex a potential DNA binder and antioxidant agent. J. Mol. Struct. 2014, 1060, 150-155. [CrossRef]

55. Lombardo, F.; Obach, R.S.; Shalaeva, M.Y.; Gao, F. Prediction of volume of distribution values in humans for neutral and basic drugs using physicochemical measurements and plasma protein binding data. J. Med. Chem. 2002, 45, 2867-2876. [CrossRef] [PubMed]

56. Huang, H.; Zhang, P.; Yu, B.; Chen, Y.; Wang, J.; Ji, L.; Chao, H. Targeting Nucleus DNA with a Cyclometalated Dipyridophenazineruthenium(II) Complex. J. Med. Chem. 2014, 57, 8971-8983. [CrossRef]

57. Bhal, S.K. LogP: Making Sense of the Value. Available online: http://www.acdlabs.com/resources/knowledgebase/app_notes/ -physchem/makingsense.php (accessed on 17 June 2018).

58. Forghieri, F.; Preti, C.; Tassi, L.; Tosi, G. Preparation, properties and reactivity of gold complexes with some heterocyclic dithiocarbamates as ligands. Polyhedron 1988, 7, 1231-1237. [CrossRef]

59. Vogler, A.; Kunkely, H. Photoreactivity of gold complexes. Coord. Chem. Rev. 2001, 219-221, 489-507. [CrossRef]

60. Calamai, P.; Guerri, A.; Messori, L.; Orioli, P.; Paolo Speroni, G. Structure and DNA binding properties of the gold(III) complex [AuCl2(esal)]. Inorg. Chim. Acta 1999, 285, 309-312. [CrossRef]

61. Philbert, L.; Xiaoyang, W. Review: Modifications of Human Serum Albumin and their Binding Effect. Curr. Pharm. Des. 2015, 21, 1862-1865. [CrossRef]

62. Katrahalli, U.; Chanabasappa Yallur, B.; Manjunatha, D.H.; Krishna, P.M. BSA interaction and DNA cleavage studies of antibacterial benzothiazol-2-yl-malonaldehyde. J. Mol. Struct. 2019, 1196, 96-104. [CrossRef]

63. Jiang, S.; Ni, H.; Liu, F.; Gu, S.; Yu, P.; Gou, Y. Binuclear Schiff base copper(II) complexes: Syntheses, crystal structures, HSA interaction and anti-cancer properties. Inorg. Chim. Acta 2020, 499, 119186. [CrossRef]

64. Sedighipoor, M.; Kianfar, A.H.; Mohammadnezhad, G.; Görls, H.; Plass, W.; Momtazi-Borojeni, A.A.; Abdollahi, E. Synthesis, crystal structure of novel unsymmetrical heterocyclic Schiff base $\mathrm{Ni}(\mathrm{II}) / \mathrm{V}(\mathrm{IV})$ complexes: Investigation of DNA binding, protein binding and in vitro cytotoxic activity. Inorg. Chim. Acta 2019, 488, 182-194. [CrossRef]

65. Atrián-Blasco, E.; Gascón, S.; Rodríguez-Yoldi, M.J.; Laguna, M.; Cerrada, E. Novel Gold(I) Thiolate Derivatives Synergistic with 5-Fluorouracil as Potential Selective Anticancer Agents in Colon Cancer. Inorg. Chem. 2017, 56, 8562-8579. [CrossRef]

66. da Silva, E.N.; da Silva, P.A.B.; Graminha, A.E.; de Oliveira, P.F.; Damasceno, J.L.; Tavares, D.C.; Batista, A.A.; Von Poelhsitz, G. Synthesis, Characterization, Cytotoxic Activity, and Interactions with CT-DNA and BSA of Cationic Ruthenium(II) Complexes Containing Dppm and Quinoline Carboxylates. Bioinorg. Chem. Appl. 2017, 2017, 2562780. [CrossRef] [PubMed]

67. Crouse, H.F.; Potoma, J.; Nejrabi, F.; Snyder, D.L.; Chohan, B.S.; Basu, S. Quenching of tryptophan fluorescence in various proteins by a series of small nickel complexes. Dalton Trans. 2012, 41, 2720-2731. [CrossRef] [PubMed]

68. Liévin-Le Moal, V.; Servin, A.L. Pathogenesis of human enterovirulent bacteria: Lessons from cultured, fully differentiated human colon cancer cell lines. Microbiol. Mol. Biol. Rev. MMBR 2013, 77, 380-439. [CrossRef] [PubMed]

69. Meunier, V.; Bourrié, M.; Berger, Y.; Fabre, G. The human intestinal epithelial cell line Caco-2; pharmacological and pharmacokinetic applications. Cell Biol. Toxicol. 1995, 11, 187-194. [CrossRef]

70. Sambuy, Y.; De Angelis, I.; Ranaldi, G.; Scarino, M.L.; Stammati, A.; Zucco, F. The Caco-2 cell line as a model of the intestinal barrier: Influence of cell and culture-related factors on Caco-2 cell functional characteristics. Cell Biol. Toxicol. 2005, 21, 1-26. [CrossRef]

71. Desai, T.J.; Toombs, J.E.; Minna, J.D.; Brekken, R.A.; Udugamasooriya, D.G. Identification of lipid-phosphatidylserine (PS) as the target of unbiasedly selected cancer specific peptide-peptoid hybrid PPS1. Oncotarget 2016, 7, 30678-30690. [CrossRef]

72. Fadok, V.A.; Voelker, D.R.; Campbell, P.A.; Cohen, J.J.; Bratton, D.L.; Henson, P.M. Exposure of phosphatidylserine on the surface of apoptotic lymphocytes triggers specific recognition and removal by macrophages. J. Immunol. 1992, 148, $2207-2216$.

73. Sorenson, C.M.; Barry, M.A.; Eastman, A. Analysis of events associated with cell cycle arrest at G2 phase and cell death induced by cisplatin. J. Natl. Cancer Inst. 1990, 82, 749-755. [CrossRef] [PubMed]

74. William-Faltaos, S.; Rouillard, D.; Lechat, P.; Bastian, G. Cell cycle arrest by oxaliplatin on cancer cells. Fundam. Clin. Pharmacol. 2007, 21, 165-172. [CrossRef]

75. Coronnello, M.; Mini, E.; Caciagli, B.; Cinellu, M.A.; Bindoli, A.; Gabbiani, C.; Messori, L. Mechanisms of Cytotoxicity of Selected Organogold(III) Compounds. J. Med. Chem. 2005, 48, 6761-6765. [CrossRef] [PubMed]

76. Dandash, F.; Léger, D.Y.; Fidanzi-Dugas, C.; Nasri, S.; Brégier, F.; Granet, R.; Karam, W.; Diab-Assaf, M.; Sol, V.; Liagre, B. In vitro anticancer activity of new gold(III) porphyrin complexes in colon cancer cells. J. Inorg. Biochem. 2017, 177, 27-38. [CrossRef] [PubMed]

77. Chen, Y.; McMillan-Ward, E.; Kong, J.; Israels, S.J.; Gibson, S.B. Oxidative stress induces autophagic cell death independent of apoptosis in transformed and cancer cells. Cell Death Differ. 2008, 15, 171-182. [CrossRef] [PubMed]

78. Pelicano, H.; Carney, D.; Huang, P. ROS stress in cancer cells and therapeutic implications. Drug Resist. Updates 2004, 7, 97-110. [CrossRef] 
79. Grigalius, I.; Petrikaite, V. Relationship between Antioxidant and Anticancer Activity of Trihydroxyflavones. Molecules 2017, 22, 2169. [CrossRef]

80. Maikoo, S.; Chakraborty, A.; Vukea, N.; Dingle, L.M.K.; Samson, W.J.; de la Mare, J.-A.; Edkins, A.L.; Booysen, I.N. Ruthenium complexes with mono- or bis-heterocyclic chelates: DNA/BSA binding, antioxidant and anticancer studies. J. Biomol. Struct. Dyn. 2020, 39, 4077-4088. [CrossRef]

81. Altun, Ö.; Şuözer, M. Synthesis, spectral analysis, antimicrobial, cytotoxicity, and antioxidant studies of gold(III) complex of caffeine. J. Coord. Chem. 2019, 72, 2091-2105. [CrossRef]

82. Sankarganesh, M.; Raja, J.D.; Revathi, N.; Solomon, R.V.; Kumar, R.S. Gold(III) complex from pyrimidine and morpholine analogue Schiff base ligand: Synthesis, characterization, DFT, TDDFT, catalytic, anticancer, molecular modeling with DNA and BSA and DNA binding studies. J. Mol. Liq. 2019, 294, 111655. [CrossRef]

83. Levine, R.L.; Williams, J.A.; Stadtman, E.R.; Shacter, E. Carbonyl assays for determination of oxidatively modified proteins. Methods Enzymol. 1994, 233, 346-357. [CrossRef] [PubMed]

84. Lauzier, A.; Normandeau-Guimond, J.; Vaillancourt-Lavigueur, V.; Boivin, V.; Charbonneau, M.; Rivard, N.; Scott, M.S.; Dubois, C.M.; Jean, S. Colorectal cancer cells respond differentially to autophagy inhibition in vivo. Sci. Rep. 2019, 9, 11316. [CrossRef] [PubMed]

85. Huang, K.-B.; Wang, F.-Y.; Tang, X.-M.; Feng, H.-W.; Chen, Z.-F.; Liu, Y.-C.; Liu, Y.-N.; Liang, H. Organometallic Gold(III) Complexes Similar to Tetrahydroisoquinoline Induce ER-Stress-Mediated Apoptosis and Pro-Death Autophagy in A549 Cancer Cells. J. Med. Chem. 2018, 61, 3478-3490. [CrossRef]

86. Zhang, J.; Zhang, Z.; Jiang, M.; Li, S.; Yuan, H.; Sun, H.; Yang, F.; Liang, H. Developing a Novel Gold(III) Agent to Treat Glioma Based on the Unique Properties of Apoferritin Nanoparticles: Inducing Lethal Autophagy and Apoptosis. J. Med. Chem. 2020, 63, 13695-13708. [CrossRef] [PubMed]

87. Mizdal, C.R.; Stefanello, S.T.; da Costa Flores, V.; Agertt, V.A.; Bonez, P.C.; Rossi, G.G.; da Silva, T.C.; Antunes Soares, F.A.; de Lourenço Marques, L.; de Campos, M.M.A. The antibacterial and anti-biofilm activity of gold-complexed sulfonamides against methicillin-resistant Staphylococcus aureus. Microb. Pathog. 2018, 123, 440-448. [CrossRef] [PubMed]

88. Sousa, S.A.; Leitão, J.H.; Silva, R.A.L.; Belo, D.; Santos, I.C.; Guerreiro, J.F.; Martins, M.; Fontinha, D.; Prudêncio, M.; Almeida, M.; et al. On the path to gold: Monoanionic Au bisdithiolate complexes with antimicrobial and antitumor activities. J. Inorg. Biochem. 2020, 202, 110904. [CrossRef] [PubMed]

89. Andrejević, T.P.; Glišić, B.Đ.; Djuran, M.I. Amino Acids and Peptides as Versatile Ligands in the Synthesis of Antiproliferative Gold Complexes. Chemistry 2020, 2, 13. [CrossRef]

90. Pintus, A.; Aragoni, M.C.; Cinellu, M.A.; Maiore, L.; Isaia, F.; Lippolis, V.; Orrù, G.; Tuveri, E.; Zucca, A.; Arca, M. [Au(pyb$\mathrm{H})(\mathrm{mnt})$ ]: A novel gold(III) 1,2-dithiolene cyclometalated complex with antimicrobial activity (pyb-H=C-deprotonated 2benzylpyridine; mnt=1,2-dicyanoethene-1,2-dithiolate). J. Inorg. Biochem. 2017, 170, 188-194. [CrossRef]

91. Noguchi, R.; Hara, A.; Sugie, A.; Nomiya, K. Synthesis of novel gold(I) complexes derived by AgCl-elimination between $[\mathrm{AuCl}(\mathrm{PPh} 3)]$ and silver(I) heterocyclic carboxylates, and their antimicrobial activities. Molecular structure of [Au(R,SHpyrrld)(PPh3)] (H2pyrrld=2-pyrrolidone-5-carboxylic acid). Inorg. Chem. Commun. 2006, 9, 355-359. [CrossRef]

92. Novelli, F.; Recine, M.; Sparatore, F.; Juliano, C. Gold(I) complexes as antimicrobial agents. Il Farm. 1999, 54, 232-236. [CrossRef]

93. Goss, C.H.A.; Henderson, W.; Wilkins, A.L.; Evans, C. Synthesis, characterisation and biological activity of gold(III) catecholate and related complexes. J. Organomet. Chem. 2003, 679, 194-201. [CrossRef]

94. Dennis, E.K.; Kim, J.H.; Parkin, S.; Awuah, S.G.; Garneau-Tsodikova, S. Distorted Gold(I)-Phosphine Complexes as Antifungal Agents. J. Med. Chem. 2020, 63, 2455-2469. [CrossRef] [PubMed]

95. Fontinha, D.; Sousa, S.A.; Morais, T.S.; Prudêncio, M.; Leitão, J.H.; Le Gal, Y.; Lorcy, D.; Silva, R.A.L.; Velho, M.F.G.; Belo, D.; et al. Gold(iii) bis(dithiolene) complexes: From molecular conductors to prospective anticancer, antimicrobial and antiplasmodial agents. Metallomics 2020, 12, 974-987. [CrossRef] [PubMed] 